Research Article

\title{
PC Cable-Stayed Bridge Main Girder Shear Lag Effects: Assessment of Single Cable Plane in Construction Stage
}

\author{
Yan-feng Li $\mathbb{D}^{1,2}$ Xing-long Sun $\mathbb{D}^{1,}{ }^{1}$ and Long-sheng Bao ${ }^{1}$ \\ ${ }^{1}$ School of Transportation Engineering, Shenyang Jianzhu University, Shenyang 110168, China \\ ${ }^{2}$ Key Laboratory of Ministry of Education on Safe Mining of Deep Metal Mines, Northeastern University, \\ Shenyang 110819, China \\ Correspondence should be addressed to Yan-feng Li; lyfneu@126.com
}

Received 9 January 2020; Revised 3 March 2020; Accepted 4 March 2020; Published 31 March 2020

Academic Editor: Dimitrios E. Manolakos

Copyright (c) 2020 Yan-feng Li et al. This is an open access article distributed under the Creative Commons Attribution License, which permits unrestricted use, distribution, and reproduction in any medium, provided the original work is properly cited.

\begin{abstract}
A model test and finite element analysis were conducted in this study to determine the distribution law of shear lag effect in the main beam section, a box girder, during the cable-stayed bridge construction process. The experimental and theoretical results were compared in an example of loading the control section. The stress value of the cable tension area of the main beam upper edge was found to markedly change when tensiling the cable force and was accompanied by prominent shear lag effect. After a hanging basket load was applied, the main beam of certain sections showed alternating positive and negative shear lag characteristics. The shear lag distribution law in the box girder of the single-cable-plane prestressed concrete cable-stayed bridge along the longitudinal direction was determined in order to observe the stress distribution of the girder. The results show that finite element analysis of the plane bar system should be conducted at different positions in the bridge under construction; the calculated shear lag coefficient of the cable force acting at the cable end of the cantilever reflects the actual force. In the beam segments between the cable forces, the shear lag coefficient determined by the ratio of the bending moment to the axial force reflects the actual stress at the cable force action point. In the midspan beam section between the action points of cable forces, the shear lag coefficient of the bending moment reflects the actual stress. The section shear lag coefficient can be obtained by linear interpolation of the beam section between the cable action point and the middle of the span.
\end{abstract}

\section{Introduction}

The main girder, a single-cable plane cable- (PC-) stayed bridge, is generally in box section form. The shear lag effect of the box girder flange is serious under compression and bending loads, and the normal stress is highly complex $[1,2]$. Shear lag causes uneven distribution of normal stress in the flange plates, which is one of the main causes of cracks in concrete box section girders $[3,4]$. The effective width is generally used to replace the actual width of the flange to calculate the effect of shear lag on box girders. The bridge codes of various countries prescribe effective width calculation methods for special structures such as simply supported beams, continuous beams, and cantilever beams, but there is no clear stipulation for cable-stayed bridge designs.
The variational principle of potential energy has been used by previous researchers to analyze the theoretical shear lag effects in concrete box beams $[5,6]$. Chang et al., for example, used the principle of minimum potential energy to analyze the shear lag effects of thin-walled trapezoidal box sections with inclined stiffeners in the cell; they found that the bridge segment presents bending stress and axial stress simultaneously and assumed the parabolic transverse change of the axial force on the section [7]. Wu and Hong established a 3D finite element model of a bridge to study the shear lag effects of cable-stayed bridges, where shear lag coefficients varied in different locations along the longitudinal axis of the bridge [8]. Pengzhen et al. used the finite element method to observe the influence of a concrete box beam with various flange depths along the orientation of cross section [9]. Yamaguchi et al. established a plate and 
shell finite element model for simply supported and continuous beams to assess the influence of finite element mesh size, load mode, width to height ratio, and width to span ratio on the stress of the box girder's wing slab [10]. Shen analyzed the shear lag effect of the main beam of a wide and short tower cable-stayed bridge to explore the warping displacement function caused by shear lag [11].

There have been many other valuable contributions to the literature as well. Xingmin used a finite element analysis method considering shear lag degrees of freedom (DOFs) to observe the influence of the construction process on box girder shear lag effects [12]. Muyu et al. used spatial finite element analysis to find that the shear lag effect of the main beam section exerts a greater impact on the structure during the construction process than after the completion of the bridge. In the cantilever construction stage of the " $T$ " structure, the main beam of the low-tower cable-stayed bridge is subjected to bending as well as massive axial force, which creates an uneven distribution of the section stress during the diffusion process. For the large-flange wide box girder, this uneven distribution of cross section stress is even more significant [13]. Qianshu et al. established an ANSYS solid finite element model to simulate the cantilever construction process; they found that the shear lag effect of the roof in the maximum cantilever stage changes from positive to negative in the cantilever direction. The shear lag coefficient trends toward stability, however, as cantilever construction progresses [14].

The extant research shows that the shear lag effect of cable-stayed bridge under cantilever construction is indeed significant, but no specific theoretical numerical results have been given for the beam sections at different positions. In the cable-stayed bridge discussed here, the beam segment is in a cantilever state during the construction process. The box girder shear lag coefficient fluctuates as the stay cable is placed continuously under tension; the shear lag effect becomes increasingly prominent as construction progresses so that the distribution law of shear lag effect on the main beam of a single-cable-plane cable-stayed bridge during construction was systematically analyzed in this study. The model test and numerical analysis results were used to analyze the distribution of shear lag in the transverse direction of the main beam section. Characteristic points with prominent shear lag along the longitudinal direction in the transverse section of the main beam were analyzed specifically in different stages of construction, and the distribution law was obtained.

Due to space limitations, this paper only presents Working Conditions 1 and 4 of the construction process for analysis. The shear lag coefficients $\lambda_{\mathrm{M}}$ caused by the bending moment and $\lambda_{N}$ caused by the axial force were, respectively, analyzed to solve the shear lag coefficient $\lambda$ after superposition. The relationship between the axial force ratio of the bending moment and the shear lag coefficient $\lambda$ is discussed in detail below. We find that different shear lag coefficients are appropriate for different beam sections of cable-stayed bridges during construction. The results presented here may have a certain reference value for similar projects.

\section{Research Background}

The Fumin Bridge (Shenyang, China) served as the research object for this study. Fumin is a single-cable PC cable-stayed bridge with a length of $420.00 \mathrm{~m}$ and a span of $89.00 m+242.00 m+89.00 m$, as shown in Figure 1(a). Its main beam is an approximate triangular section with strong wind resistance, a single box, and three chambers. Its beam height is $3.41 \mathrm{~m}$. The dimensions of each part of the middle span are shown in Figure 1(b). The thickness of each part near the root of the tower and the closing section of the middle span increase appropriately. The dimensions of each part of the side span are shown in Figure 1(c). A diaphragm can be found along every $3.15 \mathrm{~m}$ of the side span. The thickness of the middle compartment diaphragm at the section anchored by cable is $40 \mathrm{~cm}$. The thickness of the middle compartment diaphragm at the section without a cable anchorage is $28 \mathrm{~cm}$. The main tower also has a box section with a height of $67.50 \mathrm{~m}$.

The stay cable of this bridge was fabricated from $\Phi 7$ galvanized high-strength steel wire. The wire arrangement is 301-Ф7, 241-Ф7, 211-Ф7, and 151-Ф7 across four specifications in a fan layout. Each main tower has a layout of 15 pairs making 120 stay cables in total. The cable spacing on the main beam is arranged as the middle span at $14 \times 7.40 \mathrm{~m}$; the side span cable distance is $10 \times 6.30 \mathrm{~m}$; and the tail cable area is $1.50 \mathrm{~m}+1.50 \mathrm{~m}+5.75 \mathrm{~m}+7.00 \mathrm{~m}$. The distance between cable number 1 and the intersection point of the tower axis and main beam center line is $15.90 \mathrm{~m}$. The cable spacing on the tower from top to bottom is $4 \times 1.50 \mathrm{~m}+3.00 \mathrm{~m}+4.00 \mathrm{~m}+8 \times 4.50 \mathrm{~m}$. The tower beam and pier are consolidated at bridge pier number 4 . The tower and beam are consolidated, while the beam and pier are separate at bridge pier number 5 . The cantilever construction method was adopted. In the figure, the letter " $\mathrm{C}$ " represents the number of the stay cables and " $G$ " represents the number of test cross sections in the main beam.

\section{Experimental Study on Shear Lag Effect of Main Beam in Construction Stage of PC Cable-Stayed Bridge with Single Cable Plane}

3.1. Design Model. Three tenets of similarity theory were used as the basis for the structural model in this study to ensure results reflective of objective reality [15-18]. The section stiffness of the Fumin Bridge test model corresponding to the bridge prototype is similar. The test model is geometrically similar to the bridge prototype and was built with as large a scale as possible. The load of the test model was reduced according to the actual load ratio. The bridge testing model and prototype material compositions are similar as well. The test model was given the same boundary conditions as the real bridge.

The model test of cable-stayed bridge requires certain site conditions, loading conditions, and test costs. Selecting the optimal geometric scale is the primary problem to be solved in the model design process. Large-scale models are easy to make and experimental data are easy to collect from them, but costly, labor-intensive, large test sites, and loading 


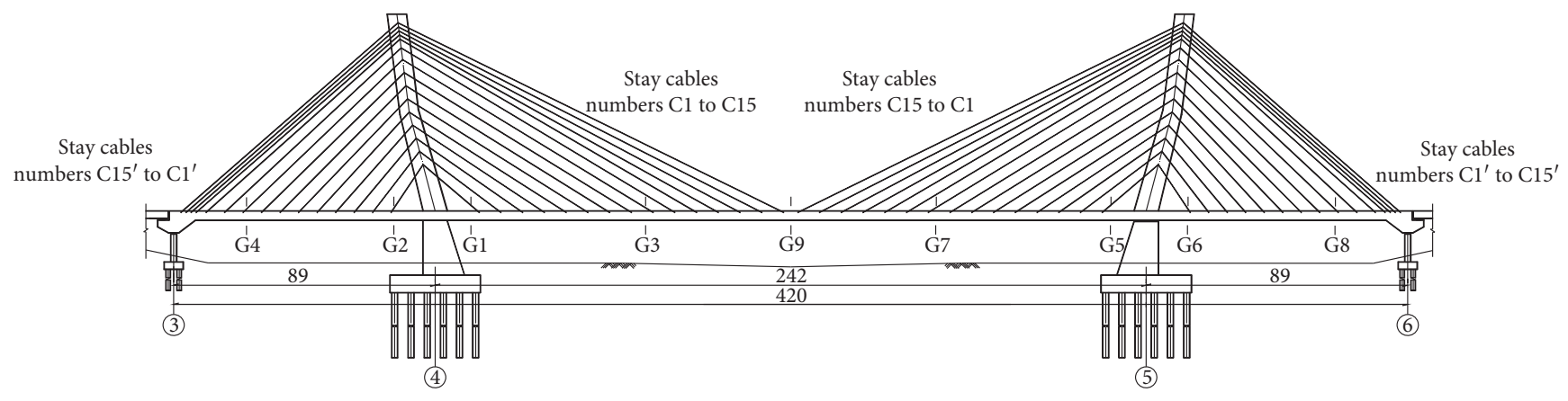

(a)

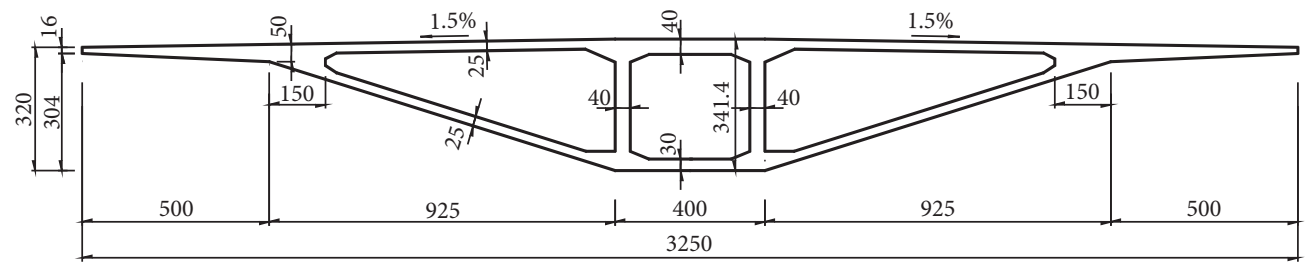

(b)

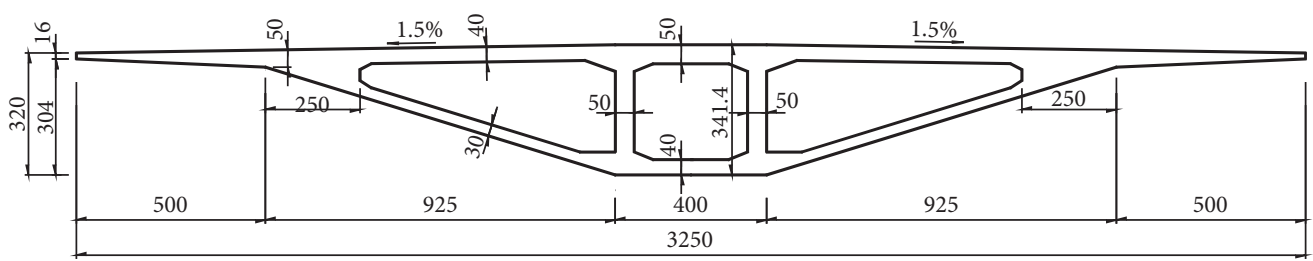

(c)

FIGURE 1: Structural drawing of bridge, (a) main bridge arrangement (unit: $\mathrm{m}$ ), (b) cross section of midspan girder (unit: $\mathrm{cm}$ ), and (c) cross section of side-span girder (unit: $\mathrm{cm}$ ).

equipment are required. A small-scale model requires only a lightweight load, but it is relatively difficult to build or equip with test instruments; further, the measurement error is relatively large. It is necessary to weigh various test conditions and requirements before selecting the most appropriate proportion for model making. Through comprehensive consideration, the geometric scaling ratio of the whole model in this study was determined to be $1: 40$ and the length of the cable-stayed bridge model was $10.5 \mathrm{~m}$.

3.1.1. Box Girder Design. The main girder of this model is made of aluminum alloy. Each section of the box girder was made from plates pulled through rivets and glued together. The elastic modulus ratio between C50 concrete and aluminum alloy is 0.50 . The section area and the moment of inertia for the model box girder can be calculated under the principle of similarity:

$$
\begin{aligned}
& A_{m}=A_{p} \cdot\left(\frac{1}{2}\right)\left(\frac{1}{40^{2}}\right), \\
& I_{m}=I_{p}\left(\frac{1}{2}\right)\left(\frac{1}{40^{4}}\right) .
\end{aligned}
$$

According to geometric similarity, the size of the box girder section model is basically unchanged. The wall thickness of the box girder was halved to ensure that the section area and the moment of inertia were similar in this analysis. Some section similarity deviation was controlled within an allowable range. The error of modulus only affects the section stress, so the model and prototype were calculated under corresponding working conditions. Their accurate similarity ratios were determined according to the strain and stress calculation results.

The box girder of the test model consists of 19 sections which may be assembled via a typical construction process. Dead load compensation was conducted by hanging heavy objects directly onto a predefined hanging point; the construction load and live load were imposed by adding heavy loads on the bridge deck. The full-bridge model is shown in Figure 2.

3.1.2. Stay Cable Design. The stay cable of model is made of high-strength steel wires, similar to the prototype cable. The elastic modulus ratio in this case is equal to 1 . The sectional area of the model stay cable is

$$
A_{m}=A_{p} \cdot\left(\frac{1}{40^{2}}\right)
$$

The girder and stay cable were connected by screw thread to allow us to adjust the stay cables easily. A vibrating wiretype load cell was installed at the joint to measure the force of the stay cable. The self-weight of the stay cable markedly 

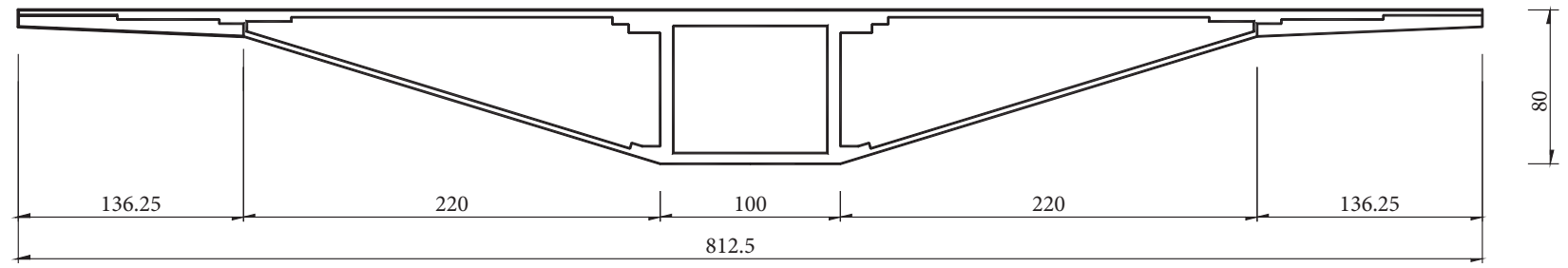

(a)

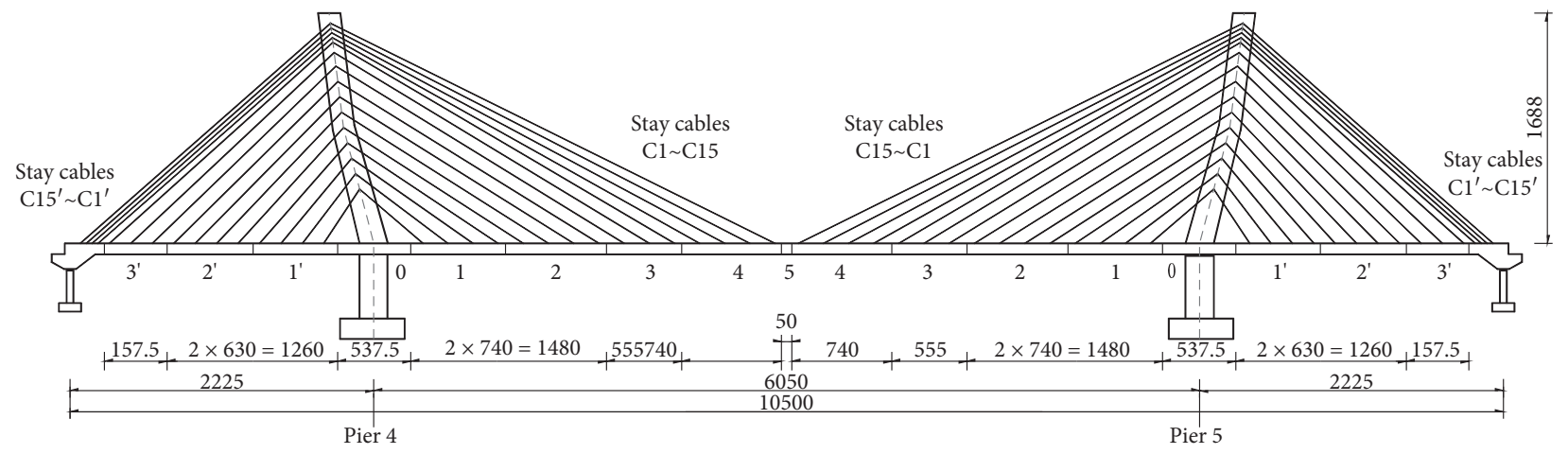

(b)

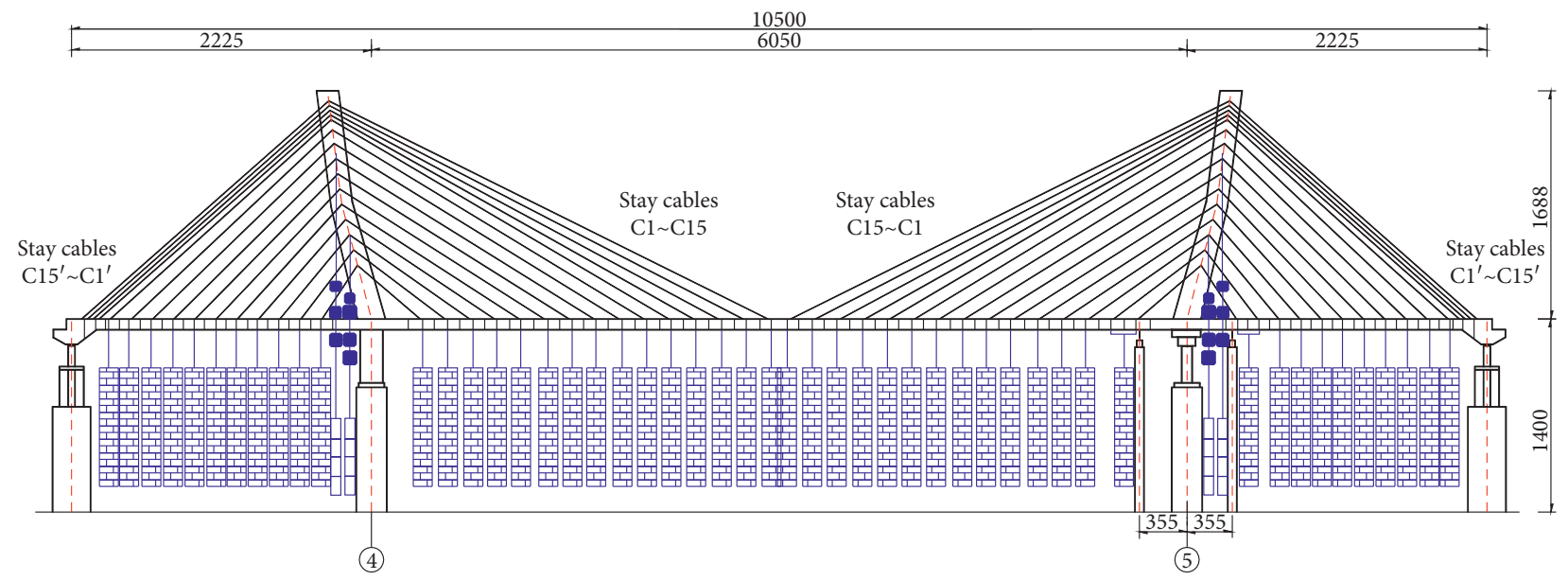

(c)

FIGURE 2: General arrangement drawing of model (unit: $\mathrm{mm}$ ), (a) midspan section diagram, (b) block diagram, and (c) temporary support and loading diagram.

influences its deformation; in order to accurately reflect the stress characteristics of the structural nonlinearity, we imposed load compensation for the dead weight of the cable via additional mass method.

3.1.3. Main Tower Design. The main tower of the cablestayed bridge was welded with Q235 B carbon structural steel. The ratio of elastic modulus to C50 concrete is 6 . According to similarity theory, the section area and moment of inertia of the main tower of the model can be calculated as follows:

$$
\begin{gathered}
A_{m}=A_{p} \cdot\left(\frac{1}{6}\right)\left(\frac{1}{40^{2}}\right), \\
I_{m}=I_{p}\left(\frac{1}{6}\right)\left(\frac{1}{40^{4}}\right) .
\end{gathered}
$$

The outer contour of the main tower section remained basically unchanged and the wall thickness was reduced by $1 / 6$ throughout this analysis to satisfy the similarity between the moment of inertia and the area of the cross section. The main tower was made in one piece and bolted into connection with the box girder. Because the main tower of the bridge was a broken line, the dead load of the main tower produced not only the stress of the tower body but also the bending moment of the tower body, which affect the entire structural system of the cable-stayed bridge internal force state. We carried out dead load compensation for the main tower to account for this.

3.1.4. Design of Bridge Pier and Bearing. The main piers and side pier were fabricated by steel welding. The box girder and Pier $4 \#$ were connected by bolts, with set bearing for Pier 3\#, 
Pier 5\#, and Pier 6\#. We set a load sensor in each bearing. A tension-applying device was used to simulate the dead load.

3.2. Model Fabrication and Installation. We used a special vibrating wire sensor to simulate the cable sensor, which was calibrated before installation to ensure long-term stability, accuracy, and reliability. In order to accurately simulate the construction process, we installed the box girder in subsection form.

According to the real-world construction requirements, Pier 5\# was set as a temporary pier and a load sensor was installed to measure the counter force of the temporary support under the action of the construction load. The model installation process is shown in Figure 3.

\subsection{Loading System and Dead Load Compensation}

3.3.1. Dead Load Compensation of the Main Tower. The dead load compensation of the main tower can be divided into two parts. There is a concentrated load which was applied via lever system. The upper segment load was applied to the center of gravity on the upper segment of the main tower. The lower segment load compensation accords with the similarity of the tower root's bending moment, which guaranteed that the tower section and tower angle section load effects were similar. The quality of the compensation for the upper segment in this test was $837.10 \mathrm{~kg}$ and that of the lower segment was $620.00 \mathrm{~kg}$.

3.3.2. Load Compensation of Main Girder. The load compensation of the main beam was applied to the diaphragm in concentrated form. The compensation quality of the intermediate span standard segment in this case was $260.30 \mathrm{~kg}$, the compensation quality of the intermediate span tower root segment was $385.30 \mathrm{~kg}$, the compensation quality of the side span standard segment was $277.20 \mathrm{~kg}$, and the intermediate span tower root segment compensation quality was $335.80 \mathrm{~kg}$. The second-stage load compensation for each lifting point included a side span of $65.00 \mathrm{~kg}$ and a middle span of $76.30 \mathrm{~kg}$.

3.4. Test Load Working Conditions and Test Contents. We installed a stay cable and box girder in accordance with the actual construction process of the original bridge. The stay cable, box girder, and main tower were gradually compensated for dead loads and the stay cable was tensioned and adjusted as necessary. The model test was carried out to simulate the construction load and stress of the girder section under the working conditions of a midspan closure in the construction stage.

3.5. Test System and Measuring Point Arrangement. Our model testing system includes a support reaction force testing component, dead load testing component, stress testing component, displacement testing component, and cable force testing component. Each fulcrum was equipped with a calibrated strain tester and a load cell to form a reaction force test system. The dead load test was performed directly on the calibrated scale. The stress testing system consists of strain gauge and resistance strain gauge. The electrical test method was used to test the live load and dead load structural stress distributions. The displacement test was performed using a level gauge, a dial gauge, and a theodolite. Our cable force test system consists of a calibrated special frequency tester and a steel string load cell. The section and measuring point arrangement we used are shown in Figures 4 and 5.

3.6. Construction Stage Working Conditions. We exampled six typical construction working conditions corresponding to real-world construction phases. In Working Condition 1 (double cantilever stage), we installed $1\left(1^{\prime}\right)$ beam section, tensioned $\mathrm{C} 1-\mathrm{C} 4\left(\mathrm{C}^{\prime}-\mathrm{C} 4^{\prime}\right)$ cables, and applied a hanging basket load. In Working Condition 2 (maximum double cantilever stage), we installed $2\left(2^{\prime}\right)$ and $3\left(3^{\prime}\right)$ beam sections, tensioned $\mathrm{C} 5-\mathrm{C} 10\left(\mathrm{C}^{\prime}-\mathrm{C} 10^{\prime}\right)$ cables, and applied a hanging basket load. In Working Condition 3, we closed the side span of number 5 pier line and applied a hanging basket load to the C11 cable. In Working Condition 4 (maximum single cantilever stage), we installed Section 4, tensioned C12-C14 $\left(\mathrm{C} 12^{\prime}-\mathrm{C} 14^{\prime}\right)$ cables, and applied a hanging basket load at the C14 cable. In Working Condition 5, we tensioned the C15 $\left(\mathrm{C} 15^{\prime}\right)$ cable and applied a closing weight to complete the midspan closure. Working Condition 6 included cable tension adjustment and application of a second-stage dead load.

\section{Test Results versus Finite Element Analysis Results}

4.1. Establishment of Finite Element Model. We used Midas/ FEA finite element software to conduct our numerical analyses. The construction scheme investigated in this study was considered a sliding formwork with a combination of the stress state of the main girder and control the main tower. The bridge was constructed via forward installation method [19-22]. In the finite element analysis, the cable was simulated by the truss unit only; the tower was simulated by the beam element. The main beam in this analysis is a solid element and a six-node tetrahedron was used for division. The full-bridge truss unit is 120 , the beam unit is 54, the solid unit is 29787, and there are 52631 nodes.

After tensioning the $\mathrm{C} 4\left(\mathrm{C}^{\prime}\right)$ cable force, the hanging basket load was $5100 \mathrm{kN}$; the boundary condition was a fixed bottom section of Pier $4 \#$ restraining the line displacement and angular displacement in the $X, Y$, and $Z$ directions. The beam and Pier 5\# were separated; the beam bottom constrained the linear displacement in $X, Y$, and $Z$ directions in this case as well. Temporary support was simulated at $14.85 \mathrm{~m}$ on the right side of the beam section of Pier 5\#, which constrained the linear displacement in the $Z$ direction.

Next, we tensioned $\mathrm{C} 10\left(\mathrm{C} 10^{\prime}\right)$ after the cable force. The hanging basket load was $5100 \mathrm{kN}$ and the boundary condition was the same as the first working condition. The side span was closed, the cable force of Pier 5\# was adjusted, and 


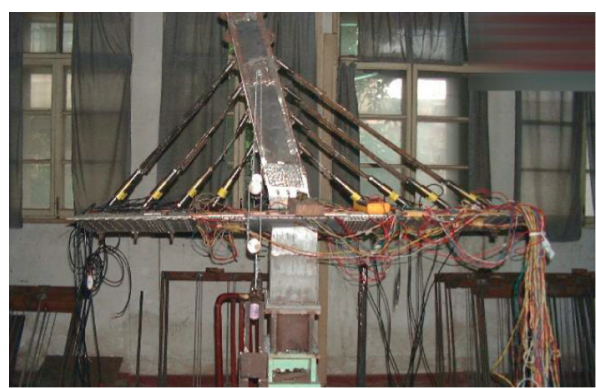

(a)

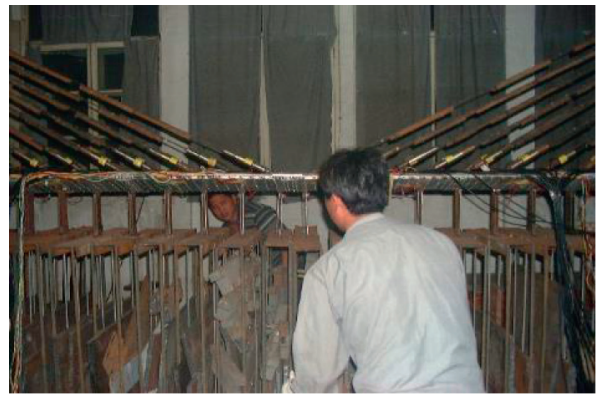

(c)

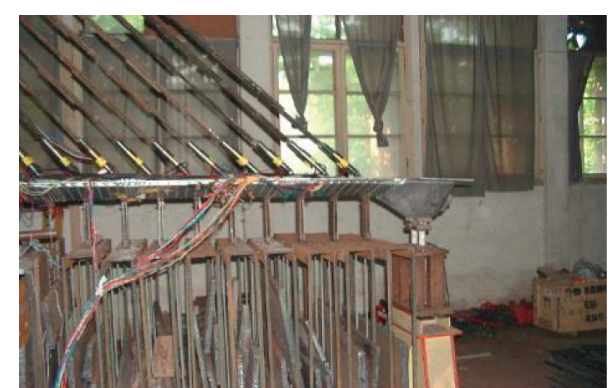

(b)

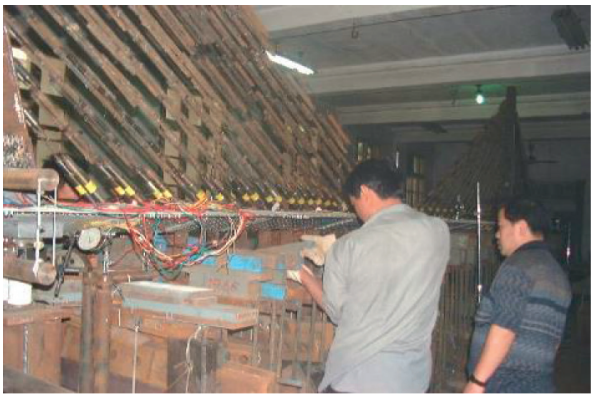

(d)

FIGURE 3: Installing the model: (a) installing four pairs of stay cables at Pier 4\#, (b) closure of side span of Pier 5\#, (c) second stage dead load applied by model, and (d) model exerts live load.

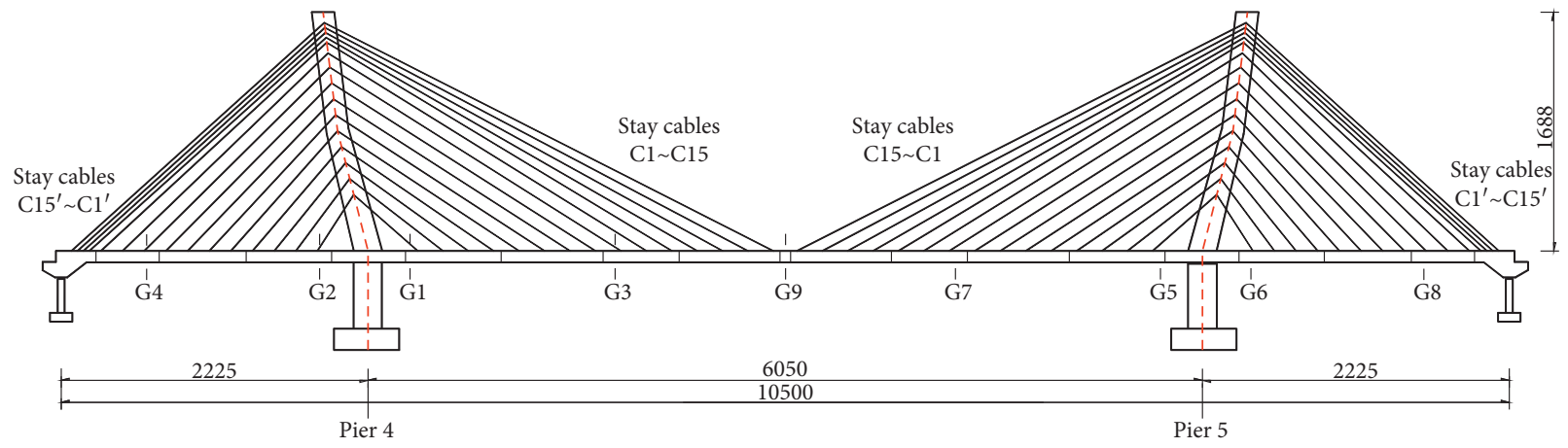

FIGURE 4: Diagram of testing section arrangement about girder (unit: $\mathrm{mm}$ ).

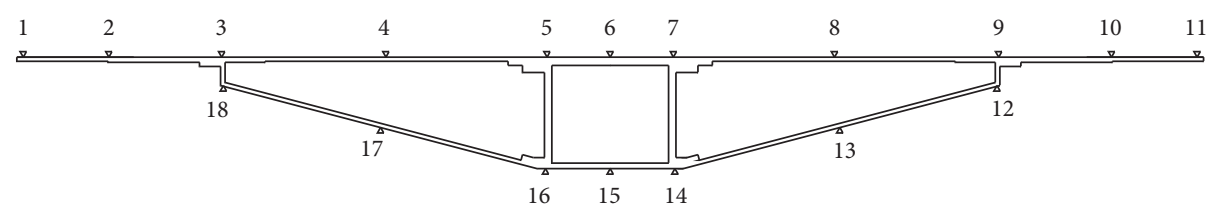

FIGURE 5: Arrangement of stiff girder stress measuring point.

the hanging basket load was $5100 \mathrm{kN}$ after the $\mathrm{C} 11\left(\mathrm{C} 11^{\prime}\right)$ cable tension was applied. The boundary condition in this case involved removed the temporary support, placing the bottom of Piers $4 \#$ and 5\# under the same working condition. The line displacement in the $Z$ direction was restrained at the end of the main beam.

After the tension of the $\mathrm{C} 14\left(\mathrm{C} 14^{\prime}\right)$ was applied, the hanging basket load was applied. At $5100 \mathrm{kN}$, the boundary conditions were the same as the previous working condition. After applying the tension of $\mathrm{C} 15\left(\mathrm{C}^{\prime} 5^{\prime}\right)$ cable force, the closing weight of $1950 \mathrm{kN}$ was applied. The middle span was closed and the closing weight was unloaded. The boundary condition in this case was an unchanged constraint on the bottom of Pier 4\#, while the line displacement of the bottom of Pier 5\# was constrained in the $Z$ direction.

The finite element model as established under these specific working conditions is shown in Figure 6. Due to limited space, only the results of Working Condition 1 and Working Condition 4 are presented here for comparison. 


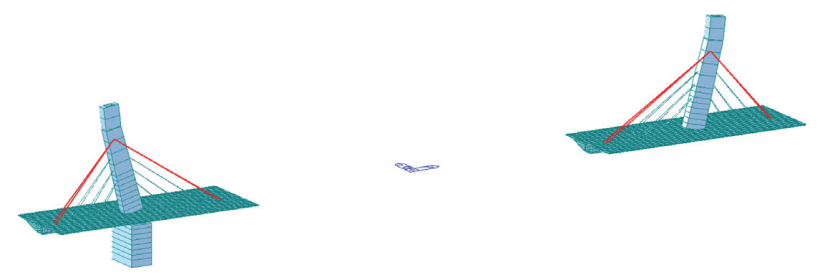

(a)

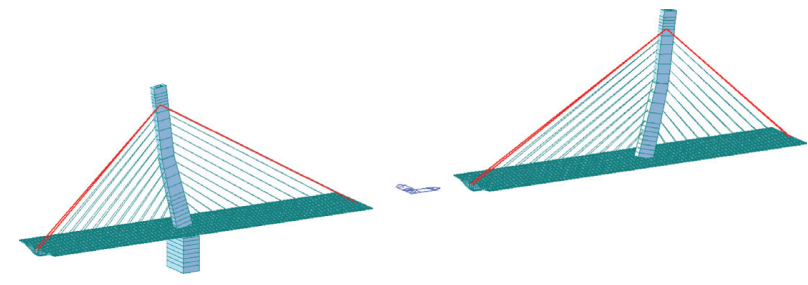

(c)

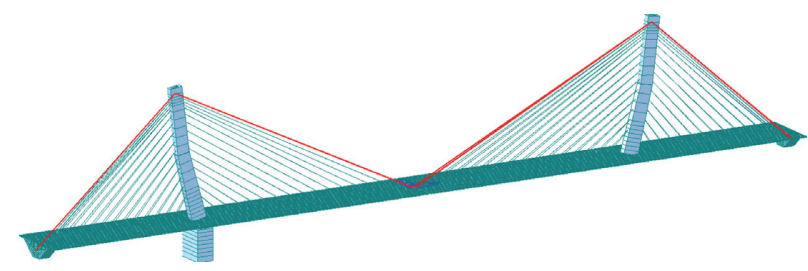

(e)

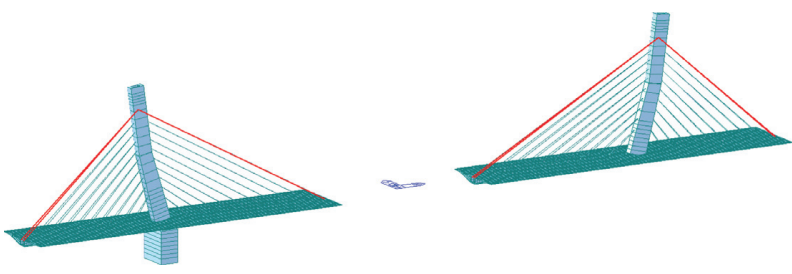

(b)

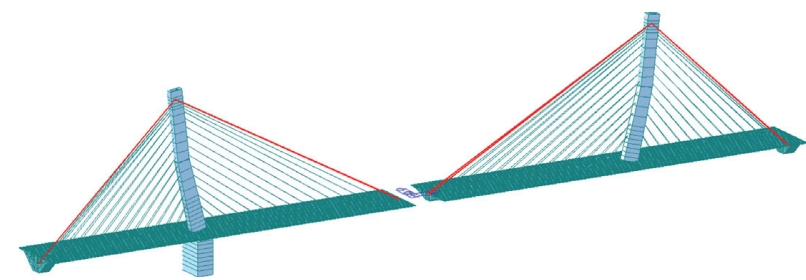

(d)

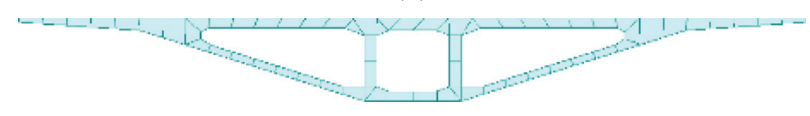

(f)

Figure 6: Special finite element model for main construction operating conditions. (a) Tension C4 (C4'), applying a basket load. (b) Tension $\mathrm{C} 10\left(\mathrm{C} 10^{\prime}\right)$, applying a basket load. (c) Cable tension adjustment, tensioning $\mathrm{C} 11\left(\mathrm{C}_{1} 1^{\prime}\right)$, applying a hanging basket load. (d) Tension $\mathrm{C} 14\left(\mathrm{C} 14^{\prime}\right)$, applying a hanging basket load. (e) Tension C15 $\left(\mathrm{C} 15^{\prime}\right)$, applying counterweight, midspan closure. (f) Grid division of main beam section.

We conducted forward installation calculations reflecting the construction process of the entire bridge. The least square method was applied to calculate of the cable force of the bridge during forward installation, and the results were compared with the reasonable cable force of the bridge until all design requirements were satisfied. At this point, the corresponding construction cable force could be considered the initial tension of the stay cable. To accelerate convergence, the initial tension of the cable was selected per the static equilibrium determined in the first forward installation iteration. Table 1 lists the initial tension of each stay cable after the iterative calculation; the number of stay cables is shown in Figure 1.

The stay cable at Pier 5\# was adjusted once the side span was closed to bring the internal force at the root of the main tower closer to the deformation at the cantilever end of the main beam. The C6 cable force was adjusted to $8000 \mathrm{kN}, \mathrm{C} 7$ cable force to $8000 \mathrm{kN}, \mathrm{C} 8$ cable force to $8000 \mathrm{kN}$, and C9 cable force to $7500 \mathrm{kN}$ at this time. Before the construction of bridge deck pavement, to ensure uniform internal force and deformation of the main girder across the whole bridge, the cable at Pier $4 \#$ was adjusted by bringing $\mathrm{C1}^{\prime}$ cable force to $9000 \mathrm{kN}, \mathrm{C} 2$ ' cable force to $9000 \mathrm{kN}, \mathrm{C} 1$ cable force to $11000 \mathrm{kN}, \mathrm{C} 2$ cable force to $11500 \mathrm{kN}, \mathrm{C} 3$ cable force to $9000 \mathrm{kN}$, and C4 cable force to $9000 \mathrm{kN}$. The cable force of part of the stay cable at Pier 5\# was also adjusted by bringing $\mathrm{C} 1$ cable force to $10000 \mathrm{kN}, \mathrm{C} 2$ cable force to $10000 \mathrm{kN}, \mathrm{Cl}^{\prime}$ cable force to $10000 \mathrm{kN}$, and C2' cable force to $10500 \mathrm{kN}$.
4.2. Main Beam Cross Section Shear Lag Coefficient under Working Condition 1. The model test results and the shear lag coefficient of the upper edge of the main beam section of Working Condition 1 in the spatial finite element were subjected to comparative analysis. After tensioning the $\mathrm{C} 4$ cable, the full beam of the main beams G1 and G2 was pressed (tensile stress is positive; compressive stress is negative); the average measured stress of the upper edge of the main beams G1 and G2 was $-2.07 \mathrm{MPa}$ and $-0.77 \mathrm{MPa}$ at this point. After applying a hanging basket load on the cantilever end of the box girder, the upper edge of the main girders G1 and G2 showed a large amount of stress changes. The midabdominal segment bore compressive stress while the upper edge of section G1 of main beam bore tensile stress. The upper edge of section G2 of main beam bore tensile stress. The average measured stress of the upper edge of the main beams G1 and G2 was $0.24 \mathrm{MPa}$ and $0.49 \mathrm{MPa}$. After the tensioning force of the main girders G1 and G2 and application of the basket load, the shear lag coefficient at each point of the upper edge was as shown in Figure 7.

After tensioning the C4 cable, the main beams G5 and G6 were pressed in the full section and the average measured stress of the upper edge of the main beams G5 and G6 was $-1.89 \mathrm{MPa}$ and $-0.53 \mathrm{MPa}$. After applying the hanging basket load on the cantilever end of the box girder, the upper edge of the main beam G5 and G6 showed a large amount of stress change. The midabdominal segment bore compressive stress and the upper edge of section G5 and G6 of main beam 
TABLE 1: Initial cable tension of each stay cable.

\begin{tabular}{|c|c|c|c|c|c|c|c|}
\hline \multicolumn{4}{|c|}{ Pier 4} & \multicolumn{4}{|c|}{ Pier 5} \\
\hline $\begin{array}{l}\text { Cable } \\
\text { number }\end{array}$ & $\begin{array}{c}\text { Tension cable force } \\
\text { (left) }(\mathrm{kN})\end{array}$ & $\begin{array}{c}\text { Cable } \\
\text { number }\end{array}$ & $\begin{array}{l}\text { Tension cable force } \\
\text { (right) }(\mathrm{kN})\end{array}$ & $\begin{array}{c}\text { Cable } \\
\text { number }\end{array}$ & $\begin{array}{l}\text { Tension cable force } \\
\text { (left) }(\mathrm{kN})\end{array}$ & $\begin{array}{c}\text { Cable } \\
\text { number }\end{array}$ & $\begin{array}{l}\text { Tension cable force } \\
\text { (right) }(\mathrm{kN})\end{array}$ \\
\hline $\mathrm{C1}^{\prime}$ & 7500 & $\mathrm{C} 1$ & 9000 & $\mathrm{C} 1$ & 9000 & $\mathrm{C} 1^{\prime}$ & 4500 \\
\hline $\mathrm{C} 2^{\prime}$ & 6500 & $\mathrm{C} 2$ & 9500 & $\mathrm{C} 2$ & 9500 & $\mathrm{C} 2^{\prime}$ & 6500 \\
\hline $\mathrm{C} 3^{\prime}$ & 5500 & $\mathrm{C} 3$ & 8000 & C3 & 8000 & $\mathrm{C} 3^{\prime}$ & 5500 \\
\hline $\mathrm{C} 4^{\prime}$ & 5500 & C4 & 8000 & $\mathrm{C} 4$ & 8000 & $\mathrm{C} 4^{\prime}$ & 5000 \\
\hline $\mathrm{C}^{\prime}$ & 5500 & C5 & 8500 & C5 & 8000 & $\mathrm{C} 5^{\prime}$ & 6000 \\
\hline C6 ${ }^{\prime}$ & 5500 & C6 & 8000 & C6 & 7400 & $\mathrm{C} 6^{\prime}$ & 6500 \\
\hline $\mathrm{C}^{\prime}$ & 5500 & C7 & 8000 & C7 & 7000 & $\mathrm{C} 7^{\prime}$ & 5500 \\
\hline $\mathrm{C} 8^{\prime}$ & 6000 & $\mathrm{C} 8$ & 8000 & C8 & 7000 & $\mathrm{C} 8^{\prime}$ & 6000 \\
\hline $\mathrm{C} 9^{\prime}$ & 6000 & C9 & 7500 & C9 & 7000 & $\mathrm{C} 9^{\prime}$ & 6000 \\
\hline $\mathrm{C} 10^{\prime}$ & 6500 & $\mathrm{C} 10$ & 7500 & C10 & 7500 & $\mathrm{C} 10^{\prime}$ & 6500 \\
\hline $\mathrm{C} 11^{\prime}$ & 6500 & C11 & 7500 & C11 & 7500 & $\mathrm{C} 11^{\prime}$ & 6500 \\
\hline $\mathrm{C} 12^{\prime}$ & 9500 & C12 & 7500 & C12 & 7500 & $\mathrm{C} 12^{\prime}$ & 9000 \\
\hline $\mathrm{C} 13^{\prime}$ & 9500 & C13 & 7500 & $\mathrm{C} 13$ & 7500 & $\mathrm{C} 13^{\prime}$ & 9000 \\
\hline $\mathrm{C} 14^{\prime}$ & 10000 & C14 & 7500 & C14 & 7500 & C14' & 9500 \\
\hline $\mathrm{C} 15^{\prime}$ & 9500 & C15 & 6500 & C15 & 6500 & $\mathrm{C} 15^{\prime}$ & 9500 \\
\hline
\end{tabular}

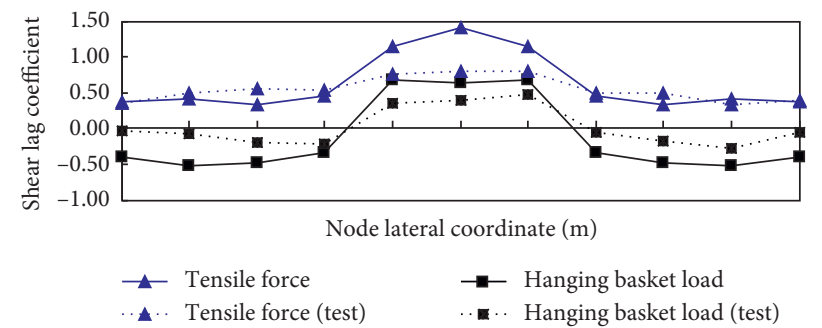

(a)

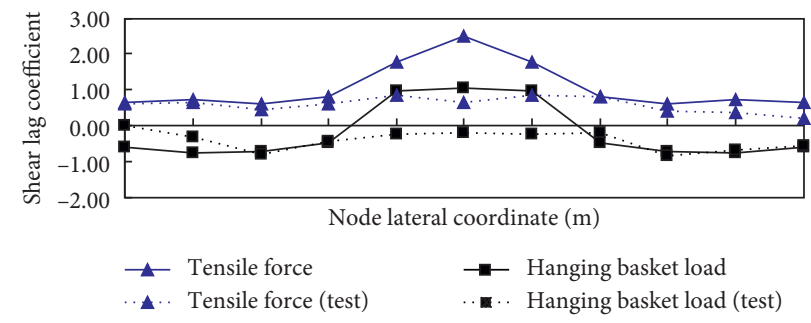

(b)

Figure 7: Shear lag coefficient variations in G1 and G2 (Condition 1): (a) G1 section; (b) G2 section.

bore tensile stress. The average measured stress of the upper edge of the main beams G5 and G6 was $0.53 \mathrm{MPa}$ and $0.55 \mathrm{MPa}$. The shear lag coefficient at each point of the upper edge was as shown in Figure 8 after the tensioning force of the main girders G5 and G6 and the application of the basket load.

As tension was applied, the concentrated load was placed in the middle of the box girder to intuitively observe the shear lag effect in the middle of the box girder section. The hanging basket load was applied in the form of a concentrated load, so that the upper edge of sections G1, G5, and G6 of the main beam presented tensile stress though the middle web section did not. After the tensile force and the hanging basket load were applied, positive and negative shear lag effects appeared alternately on the upper edge of the main beam.

4.3. Main Beam Cross Section Shear Lag Coefficient under Working Condition 4. The model test results and the shear lag coefficient of the upper edge of the main beams G1-G8 section under Working Condition 4 for the spatial finite element was also extracted for comparative analysis. As shown in Figures 9 and 10, the shear lag coefficient of the upper edge of the section G7 of the main beam changed from 0.09-2.29 to $-2.93-2.10$ after the tension of the cable and the application of the hanging basket load. The shear lag coefficient of the upper edge of the main beam G3 changed from $0.55-1.35$ to $0.39-2.32$, the shear lag coefficient of the upper edge of the main beam G4 changed from $0.63-1.59$ to $0.66-1.66$, and the shear lag coefficient of the upper edge of the main beam G8 changed from $0.34-1.52$ to $0.21-1.92$. In this case, after the tension was applied to the C14 cable and the hanging basket load was applied, the shear lag coefficient of the upper edge decelerated and the changes were slight. The shear lag coefficient of the upper edge of the sections G2 and G1, G5, and G6 of the main girder near the tower root was weak. In each section, the shear lag coefficient of the upper edge decelerated as tension cable force increased. The test results are consistent with the finite element calculation results.

\section{Longitudinal Shear Lag Effect in Main Beam of Single-Cable Plane P C Cable- Stayed Bridge}

The stress on the main girder section of cable-stayed bridge is highly complex. The construction of the cable-stayed bridge is a dynamic process. The stress in the main beam section under different working conditions and different beam sections may widely differ. The shear lag coefficient calculation results along the longitudinal length of several key nodes on the upper edge of the cross section of the main 


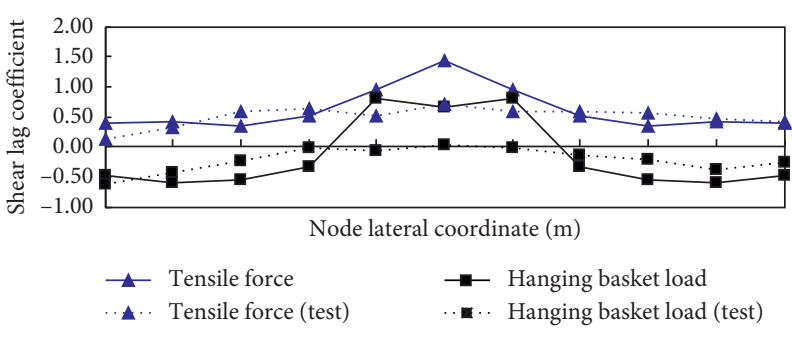

(a)

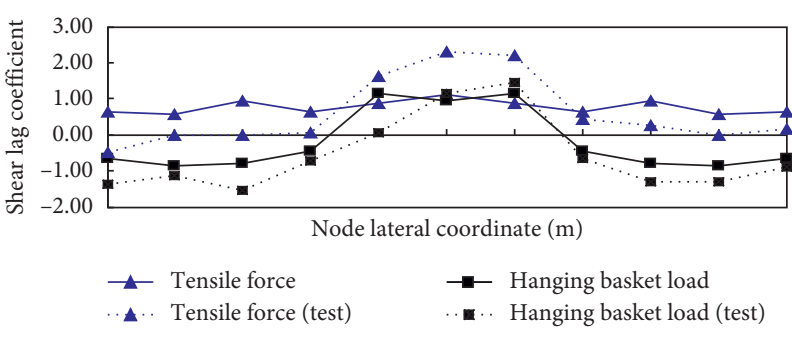

(b)

Figure 8: Shear lag coefficient variations in G5 and G6 (Condition 1): (a) G5 section; (b) G6 section.

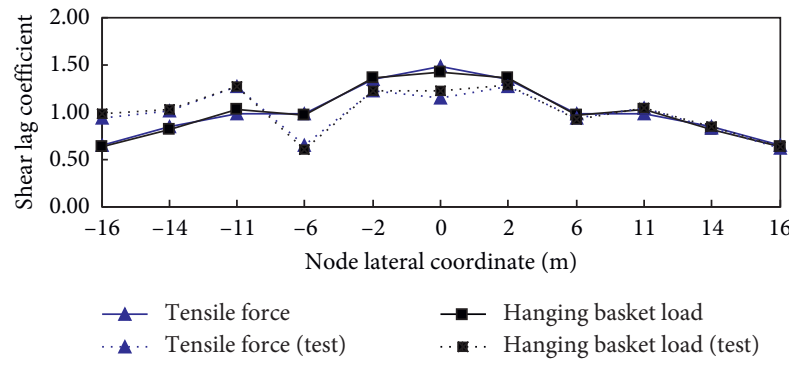

(a)

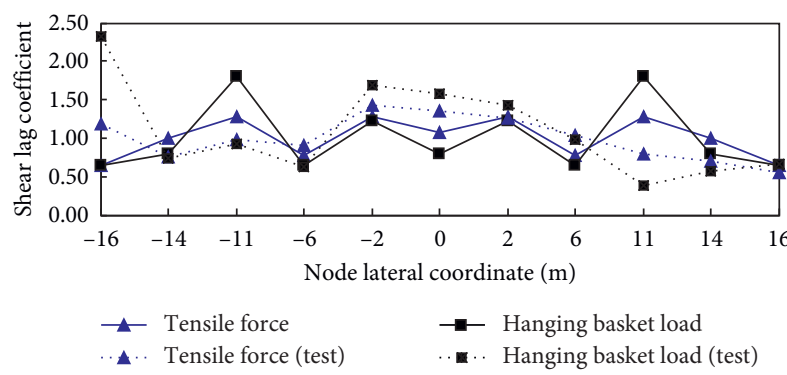

(c)

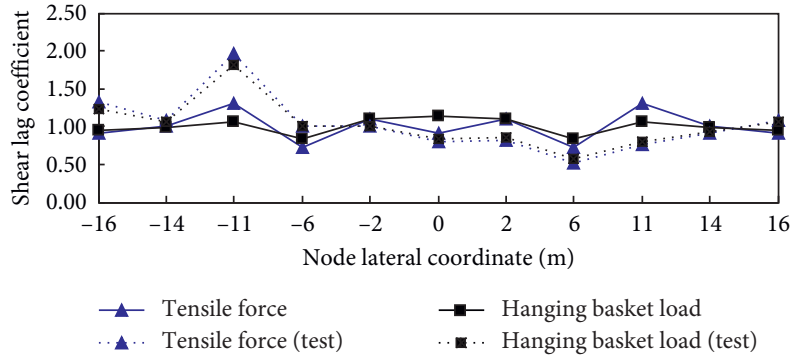

(b)

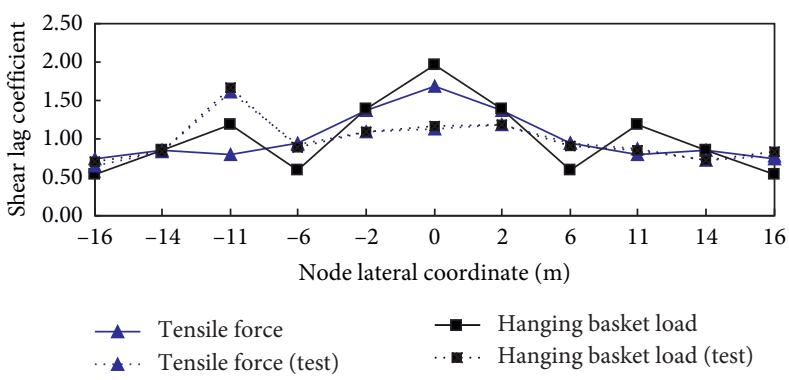

(d)

Figure 9: Contrast diagram of shear lag coefficient in G1-G4 (Condition 4): (a) G1 section, (b) G2 section, (c) G3 section, and (d) G4 section.

beam can be used to understand the shear lag coefficient distribution along the longitudinal length of the upper edge of the main beam section during the construction stage. For convenience, the key points on the top edge of the cross section of the main beam are marked here with capital letters. The distances from A-D points to the transverse symmetry lines are $0 \mathrm{~m},-2 \mathrm{~m},-11 \mathrm{~m}$, and $-16 \mathrm{~m}$, respectively. The lateral position of each point is shown in Figure 11.

Due to space limitations, only the distribution of the shear lag coefficient along the longitudinal length of the upper edge of the main beam section under the following two typical working conditions is described here. Working Condition 1 is defined by tensiling the $\mathrm{C} 4\left(\mathrm{C} 4^{\prime}\right)$ cable force; Working Condition 4 is defined by tensiling the $\mathrm{C} 14$ (C14') cable force. The boundary conditions of each working condition were kept consistent. Bridge. Under the action of self-weight and cable force, the shear lag coefficient of the flange of the main beam section along the longitudinal bridge was observed as shown in Figure 12. In the longitudinal distribution of the shear lag coefficient at the key point of the upper flange, the midpoint of the cross section of the main beam (Point A) and the boundary point between the upper edge and the middle web (Point B) change most sharply.

At Pier 4\#, a sudden change in shear lag coefficient at the end of the cantilever occurred due to the tension of the $\mathrm{C} 4$ $\left(\mathrm{C} 4^{\prime}\right)$ cable. A large stress concentration occurred at these concentrated load points which altered the upper flange stress distribution law. Under the action of cable force, the upper edge of the main beam section shows a more significant shear lag effect of the cable tension zone at locations closer to the cable action point. At Point A, the shear lag coefficient reaches 4.18; at Point B, it is 3.07. The stress distribution of the main beam appears to grow more uniform as the distance between the main beam and the cable force increases.

Pier 4\#, C3-C1 $\left(\mathrm{C}^{\prime}-\mathrm{C} 1^{\prime}\right)$, shows a similar distribution pattern in each beam section. The shear lag coefficient of 


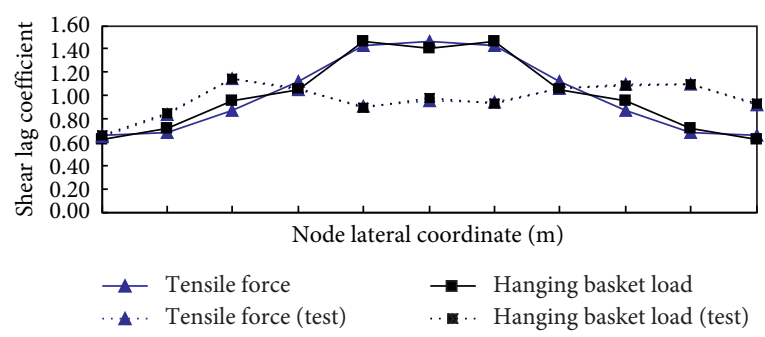

(a)

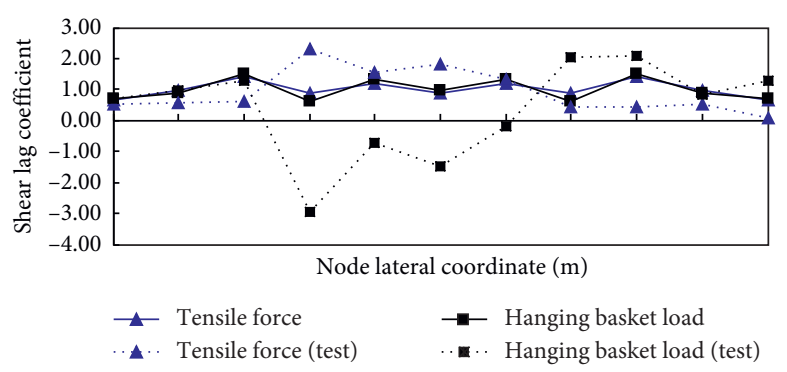

(c)

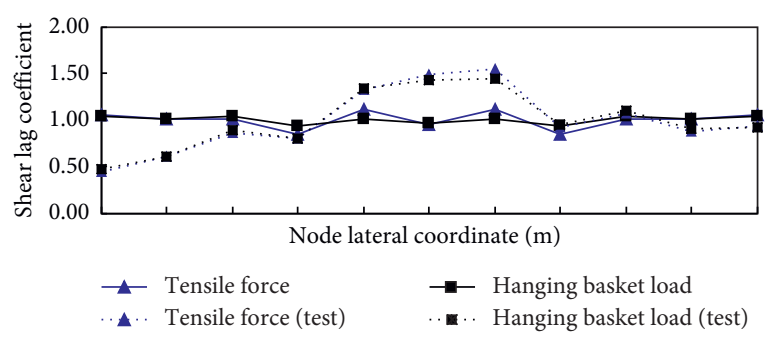

(b)

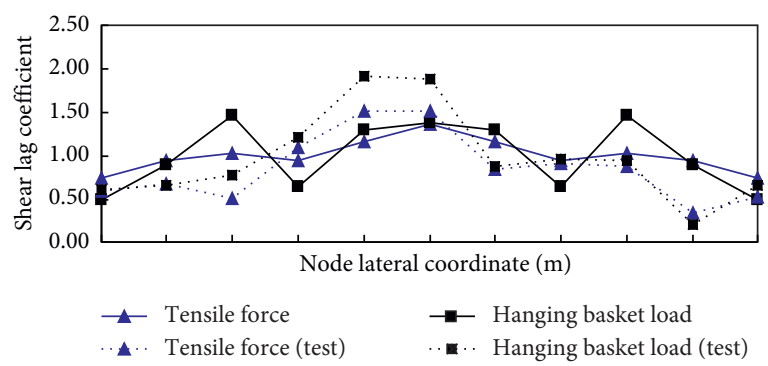

(d)

FIGURe 10: Contrast diagram of shear lag coefficient in G1-G4 (Condition 4): (a) G5 section, (b) G6 section, (c) G7 section, and (d) G8 section.

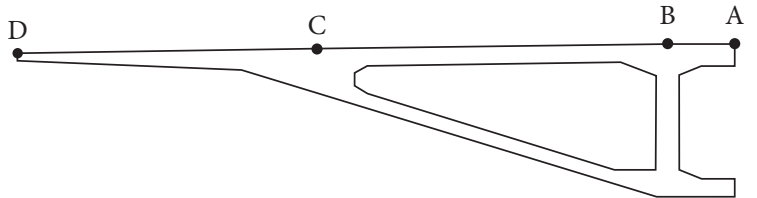

Figure 11: Main girder cross-section diagram at every point.

Point $\mathrm{A}$ and Point $\mathrm{B}$ is prominent at the point of action of the cable force. The change range of shear lag coefficient of Point $\mathrm{A}$ at the point of cable force action is $2.22-2.71$ and at Point $\mathrm{B}$ is $1.22-2.12$. The stress distribution of the beam section between the points of cable force is relatively uniform. The A-point shear lag coefficient $\lambda$ ranges from 1.15 to 1.16 , the B-point shear lag coefficient $\lambda$ from 1.12 to 1.40 , and the C-point shear lag coefficient $\lambda$ from 1.09 to 1.26 .

The stress distribution of the upper flange of the Pier 4\# tower root section changed due to the existence of the cross beam. The change appears to be most dramatic at Point $\mathrm{D}$, at the end of the upper extension arm of the main beam cross section. The shear lag coefficient $\lambda$ at Point $D$ near the tower ranges from 1.14 to 1.54 , marking a very significant variation compared with other beam sections.

The variation of the cantilever end, the cable force point, and the $\mathrm{C} 3-\mathrm{C} 1\left(\mathrm{C}^{\prime}-\mathrm{C1}^{\prime}\right)$ beam section of Pier 5\# is similar to that of Pier 4\#. Under the action of the tension C4 $\left(\mathrm{C}^{\prime}\right)$, Point A here shows a shear lag coefficient $\lambda$ of 3.00, while that at Point $\mathrm{B}$ reaches 2.50 . In our analysis, the stress distribution of the main beam grew more uniform as the distance between the main beam and the cable force increased.

Pier 5\#, C3-C1 $\left(\mathrm{C}^{\prime}-\mathrm{C} 1^{\prime}\right)$, shows a similar distribution pattern in each beam section. The shear force lag coefficient of Point A and Point B is prominent at the point of action of the cable force. The variation range of lag coefficient $\lambda$ is $1.57-2.44$, and the shear lag coefficient $\lambda$ of Point B is $1.38-1.84$ at the point of action of cable force. The stress distribution of the beam section between the cable force points is relatively uniform. The changes in shear lag coefficient $\lambda$ of Point A range from 1.41 to 1.66, that at Point $B$ varies from 1.07 to 1.57 , and that at Point $C$ ranges from 0.75 to 1.08 . Again, the most significant change was observed at Point $\mathrm{D}$; the shear lag coefficient $\lambda$ of Pier 5\# at point $\mathrm{D}$ near the tower root varies from 1.20 to 1.33 .

At the $\mathrm{C} 1^{\prime}$ cable force on the right side of Pier 5\#, the shear lag coefficient of Points A and B is weaker than at other points of cable force mainly because of the temporary support. The shear lag effects on both sides were similar due to the small reaction force of the temporary pier.

Under the action of self-weight and cable force with this working condition, the main characteristics of the shear lag effect of the upper edge of the main beam section of the single-cable PC cable-stayed bridge in the longitudinal direction can be summarized as follows:

(1) In the construction stage, under the action of cable force and near the point of cable tension, the upper edge of the girder section shows more significant shear lag effect in the cable force tension area. The girder stress distribution grows more uniform as the distance between the girder section and the cable force action point increases.

(2) In the $\mathrm{C} 3-\mathrm{C} 1\left(\mathrm{C3}^{\prime}-\mathrm{Cl}^{\prime}\right)$ beam section, the upper edge of the main beam section at the cable force action point presents shear lag effects in the tension zone. The stress distribution in the beam section between the points of the cable force is relatively uniform, which characterizes the shear lag distribution in the ordinary curved box girder. 


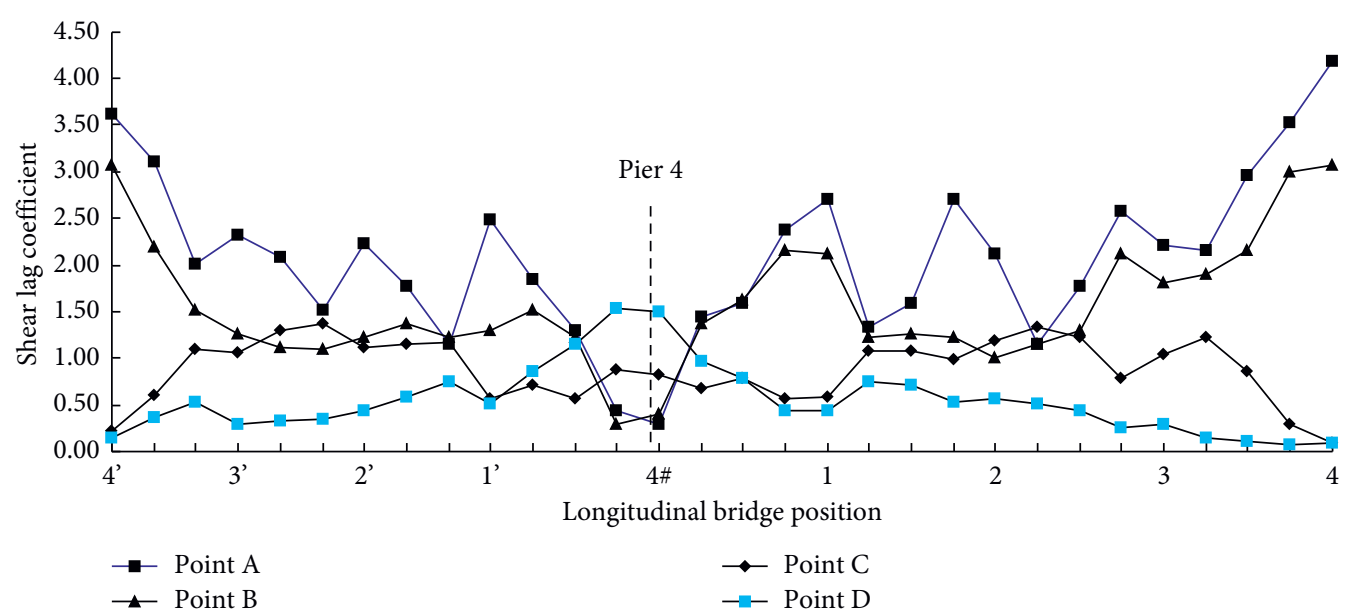

(a)

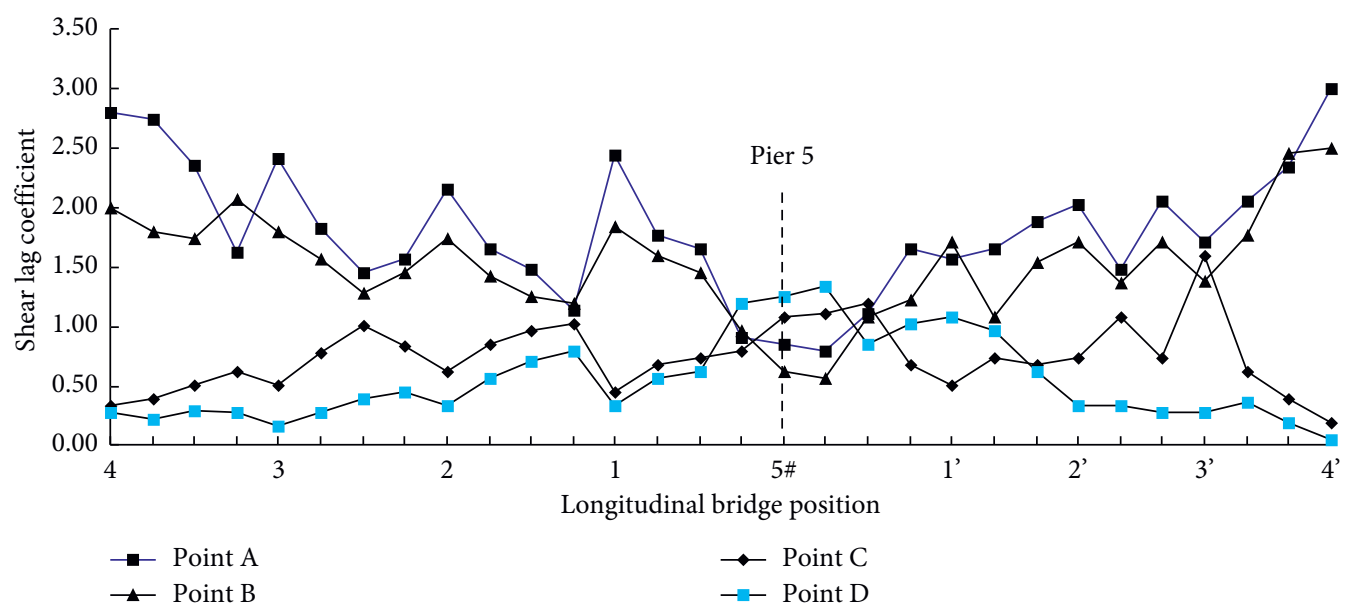

(b)

Figure 12: Distribution of shear lag coefficient along longitudinal direction (Condition 1): (a) Pier 4\#; (b) Pier 5\#.

(3) The shear lag coefficient at the end of the upper extension arm of the cross section of the main beam at the root of the tower changes most dramatically among the areas we observed. We also observed conversion from a positive shear lag effect to a negative shear lag effect near the tower.

(4) Under the influence of temporary support, the shear force lag coefficient of the action point of the $\mathrm{Cl}^{\prime}$ cable force on the right side of Pier $5 \#$ is weaker than other cable forces. The temporary pier reaction force is small, which makes the shear lag on both sides. The effects were still relatively similar in this case.

\subsection{Working Condition 4: Shear Lag Effect along Longitudinal} Bridge. This working condition represents the largest single cantilever stage. The side spans at this point are closed and the shear lag effects near their supports have markedly increased due to tensioning of $\mathrm{C} 12^{\prime}-\mathrm{C} 14^{\prime}$ tails. The shear lag effect of the inner beam section of the side span $\mathrm{C} 11^{\prime}-\mathrm{Cl}^{\prime}$ is lower than under the previous working condition.
As shown in Figure 13, at Pier 4\#, the cantilever end falls under the action of tensioning $\mathrm{C} 14$ cable force. The shear lag coefficient $\lambda$ at Point $A$ reaches 3.40 and at Point $B$ is 2.40. In

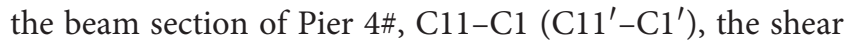
lag coefficient of Points A and B is prominent at the point of action of the cable force. Point A shows a shear lag coefficient $\lambda$ of 1.51-2.81 at the cable force action point where Point $B$ shows a shear lag coefficient $\lambda$ of $4.35-2.12$; the stress distribution of the beam section between the points of the cable force is relatively uniform. The shear lag coefficient $\lambda$ of Point A varies from 1.05 to 1.44 and that of Point B from 1.19 to 1.10 . The shear lag coefficient $\lambda$ of Point $C$ ranges from 0.65 to 0.95 .

At Pier 5\#, the end of the cantilever is under the action of the tensioning force of C14. The shear lag coefficient $\lambda$ of Point A reaches 3.57 and that of Point $\mathrm{B}$ is 2.22. In the beam section of $\mathrm{C} 11-\mathrm{C} 1\left(\mathrm{C}_{1} 1^{\prime}-\mathrm{C} 1^{\prime}\right)$ in Pier 5\#, the shear lag coefficients of Points A and B at the point of action of the cable force are prominent. Point A has a shear lag coefficient $\lambda$ of 1.48-2.81 at the action point of the cable force, where Point B has a shear lag coefficient $\lambda$ of 1.33-2.12. The stress distribution of beam section between the points of cable 


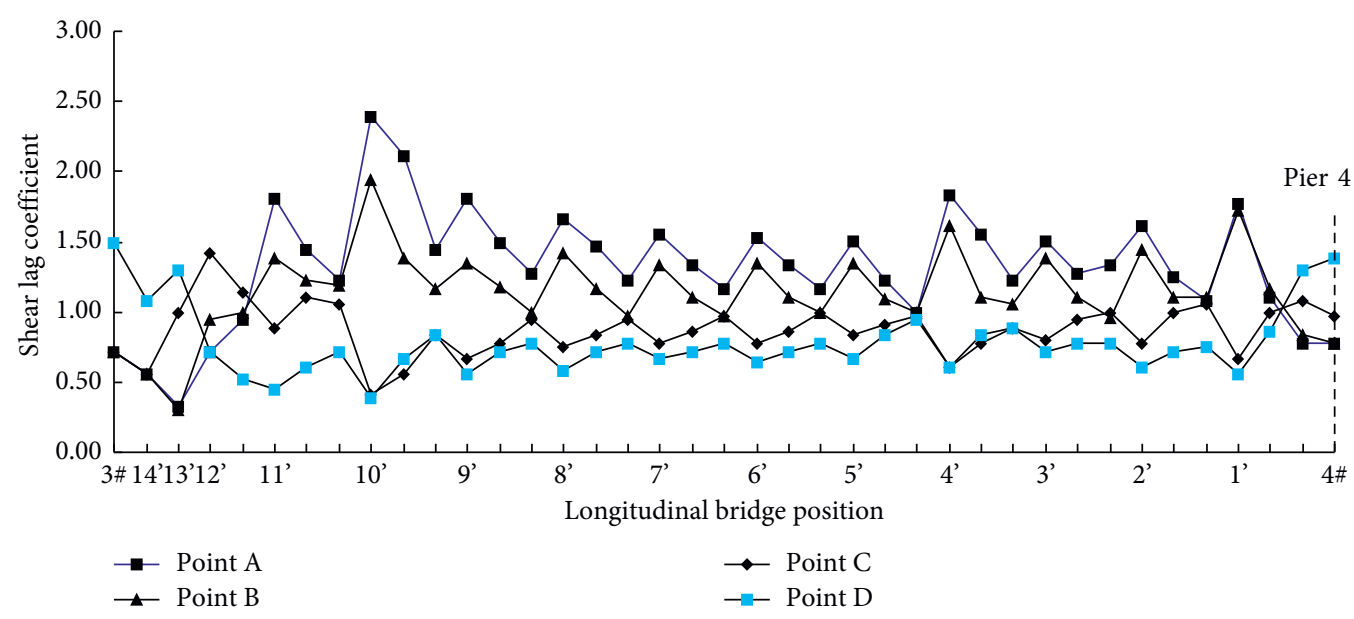

(a)

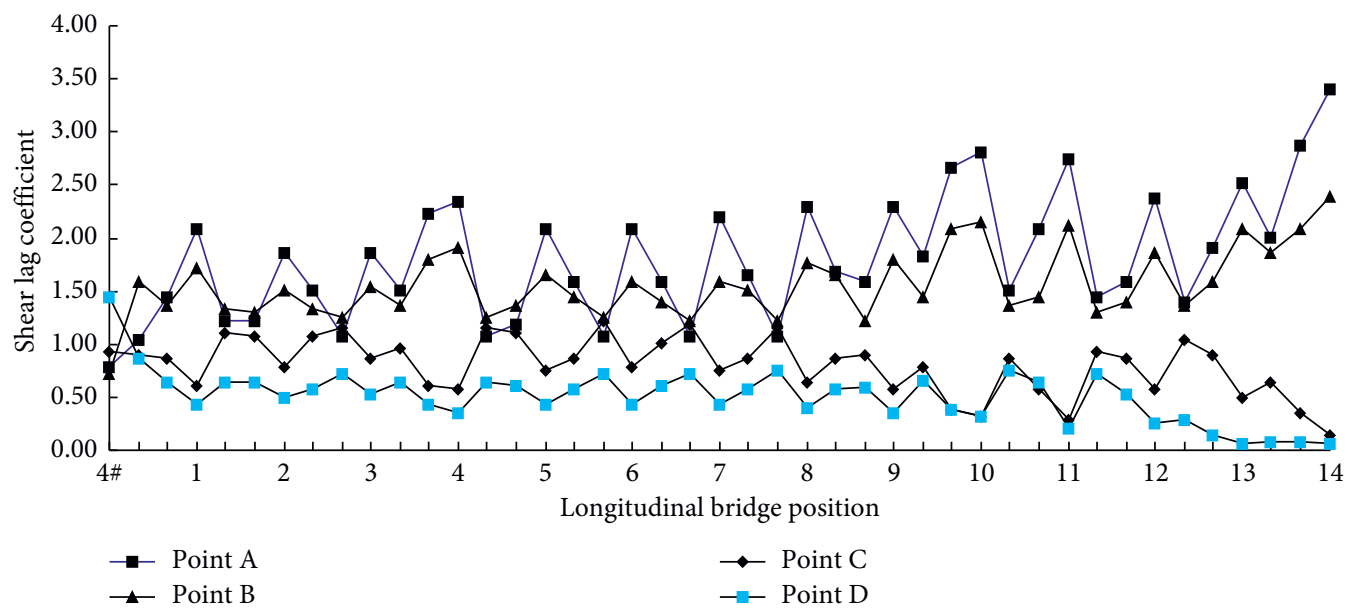

(b)

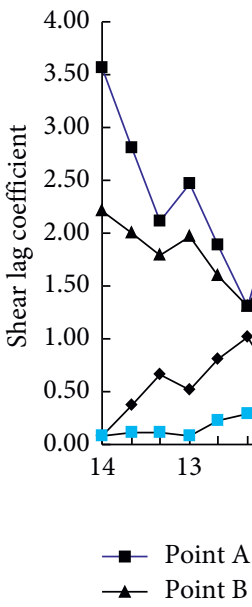

Pier 5

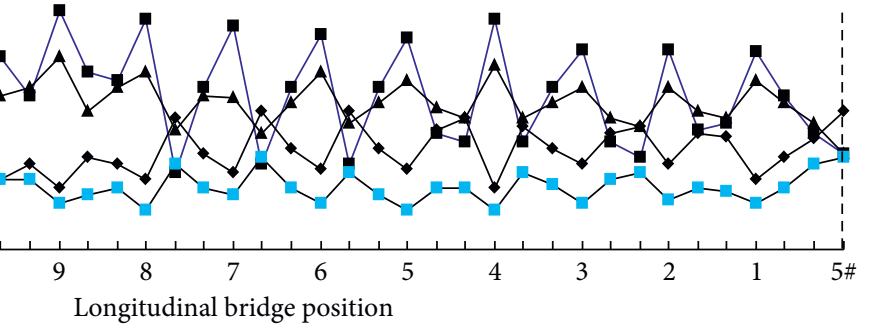

$\rightarrow$ Point $\mathrm{C}$

(c)

Figure 13: Continued. 


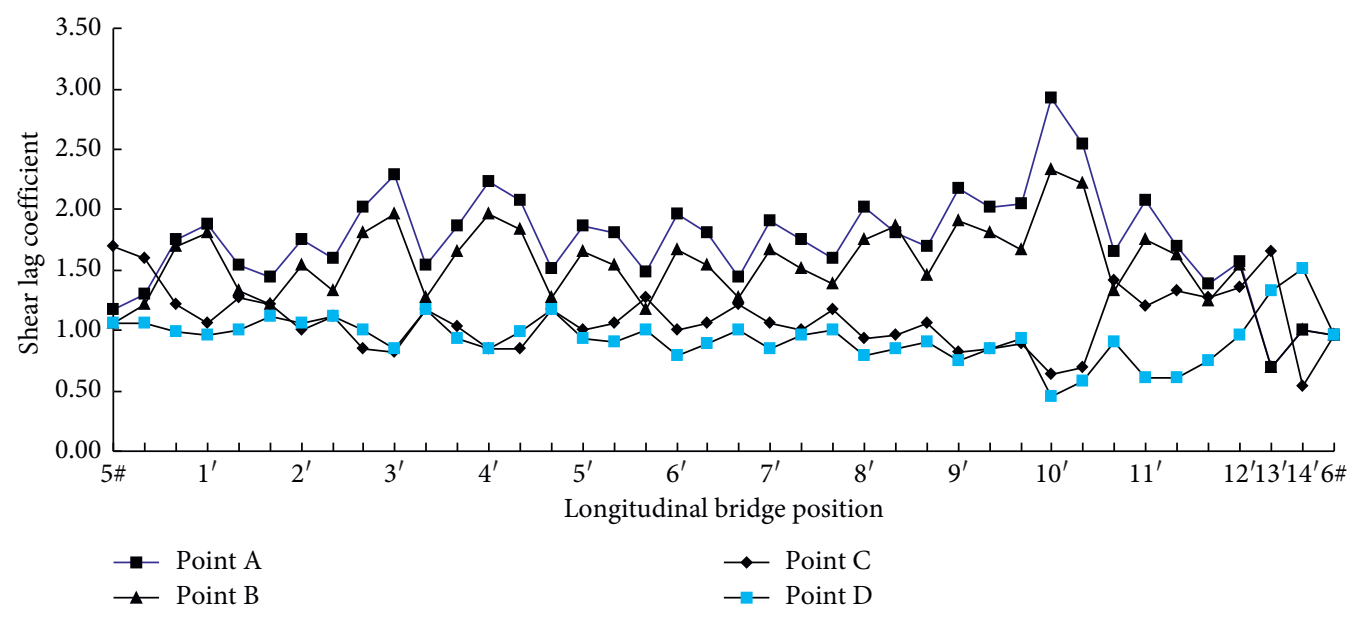

(d)

Figure 13: Distribution of shear lag coefficient along longitudinal direction (Condition 4). (a) Left side of Pier 4\#. (b) Right side of Pier 4\#. (c) Left side of Pier 5\#. (d) Right side of Pier 5\#.

force is relatively uniform. The shear lag coefficient $\lambda$ of Point A ranges from 1.20 to 1.55 , that of Point B from 0.96 to 1.35, and that of Point $\mathrm{C}$ from 0.76 to 1.01 .

Under this working condition, the action of self-weight and cable force make the main characteristics of the shear lag at the upper edge of the main beam section of the singlecable PC cable-stayed bridge along the vertical direction very similar to those of under Working Condition 1 . The shear lag effect at the main beam section is reduced as cable force increases.

\section{Distribution of Shear Lag Effect during Construction Stage}

6.1. Shear Lag Coefficient of Main Beam of Single-Cable Plane PC Cable-Stayed Bridge. The solution to the shear lag coefficient under the compressive bending load involves decomposing the compressive bending load into a superposition of the bending moment action and the axial force action, then calculating the normal stress of the main beam under the action of the bending moment and the axial force alone [22]. It is assumed that the axial force is borne by the whole section; that is, the normal stress generated by the axial force is evenly distributed along the cross section. The results can then be linearly superposed to obtain the comprehensive shear lag effect coefficient. Our previous analysis indicated that when there is cable tension of the main beam of the cable-stayed bridge in the single-cable PC, there is a large stress concentration at the point of action of the concentrated loads. The stress distribution law of the roof plate changes accordingly.

Assume that the axial force which is borne by the whole section does not reflect the actual internal force of the main girder of the single-cable PC cable-stayed bridge. The distribution of the longitudinal normal stress generated by internal force is not uniform. The size and distribution law are related to the internal force state, namely, the bending moment and axial force. In this study, the shear lag coefficient $\lambda_{\mathrm{M}}$ generated by bending moment and the shear lag coefficient $\lambda_{\mathrm{M}}$ generated by axial force were, respectively, calculated to solve the shear lag coefficient $\lambda$ after superposition.

The shear lag coefficient is calculated as follows:

$$
\lambda=\frac{\sigma}{\bar{\sigma}}
$$

where $\sigma$ is actual stress and $\sigma\left({ }_{-}\right)$is nominal stress.

The shear lag coefficient is related to the wide span ratio, support conditions, load form, cross-sectional shape and size, material properties, and location of the section [23-25]. In the final analysis, the shear lag is caused by uneven distribution of the longitudinal normal stress caused by internal force; its size and distribution are related to the internal force state; that is, the bending moment is related to the axial force.

The actual stress $\sigma$ and nominal stress $\sigma\left({ }_{-}\right)$are the superposition of the bending moment and the normal stress generated by the axial force. If the shear lag coefficient $\lambda_{\mathrm{M}}$ produced by the bending moment is defined properly, the shear lag coefficient generated by the axial force is $\lambda_{N}$, and the shear lag coefficient after the superposition is $\lambda$. Thus,

$$
\lambda=\frac{\sigma_{N}+\sigma_{M}}{\bar{\sigma}_{N}+\bar{\sigma}_{M}}=\frac{\lambda_{N} \bar{\sigma}_{N}+\lambda_{M} \bar{\sigma}_{M}}{\bar{\sigma}_{N}+\bar{\sigma}_{M}},
$$

where $\sigma\left({ }_{-}\right)_{N}$ and $\sigma\left({ }_{-}\right)_{M}$ are the nominal normal stress generated by bending moment and axial force, respectively; $\sigma\left({ }_{-}\right)_{N}$ and $\sigma\left({ }_{-}\right)_{M}$ are the actual normal stress generated by bending moment and axial force, respectively. The numerator and denominator at the right end of the above formula are divided by $\sigma\left({ }_{-}\right)_{N}$ to rewrite (7) as

$$
\lambda=\frac{\lambda_{N}+\lambda_{M}\left(\bar{\sigma}_{M} / \sigma_{N}\right)}{1+\left(\bar{\sigma}_{M} / \sigma_{N}\right)} .
$$

There are $\bar{\sigma}_{M}=(M / I) y$ and $\bar{\sigma}_{N}=(N / A)$, so $\left(\bar{\sigma}_{M} / \sigma_{N}\right)=(y A / I) \cdot(M / N)$, and order $y A / I=C$ can be plugged into (8) to obtain 


$$
\lambda=\frac{\lambda_{N}+C \lambda_{M}(M / N)}{1+C(M / N)},
$$

where $y$ is the distance from the centroid of the section to the upper and lower edges, $A$ is the sectional area, $I$ is the section moment of inertia, and $M$ and $N$ represent the bending moment and axial force of the section.

Equation (9) indicates that $y, A$, and $I$ are the parameters inherent to the section under analysis; $\lambda_{N}$ and $\lambda_{\mathrm{M}}$ are the shear lag coefficients caused by the axial force and the bending moment, respectively, which are independent of the magnitude of the internal force. Once $\lambda_{N}$ and $\lambda_{\mathrm{M}}$ are determined, the total shear lag coefficient of $\lambda$ is only related to the ratio of bending moment to axial force.

Figure 14 shows the curve of the shear lag coefficient with the bending moment axial force ratio when $\lambda_{\mathrm{M}}=2.00$ and $\lambda_{N}=1.00$. Taking the upper flange of the main beam of the Fumin cable-stayed bridge as an example, $C=y A$ / $I=1.01$.

As shown in Figure 14, the total shear lag coefficient $\lambda$ gradually approaches the bending moment shear lag coefficient $\lambda_{\mathrm{M}}$ as the bending moment force ratio increases. As the bending moment axial force ratio gradually decreases to 0 , the total shear lag coefficient $\lambda$ is also gradually reduced until it is equal to the axial force shear lag coefficient $\lambda_{N}$. When the bending moment force ratio is between 0 and 2 , the total shear lag coefficient $\lambda$ changes substantially. A larger $\lambda_{\mathrm{M}}$ results in a greater change in the total shear lag coefficient $\lambda$. When the bending moment force ratio is greater than 2 , the total shear lag coefficient $\lambda$ changes slowly. That is to say, in the internal force of this section, whether the bending moment or axial force accounts for a larger proportion affects how close the total shear lag coefficient $\lambda$ of the section is to the shear lag coefficient $\left(\lambda_{M}\right.$ or $\lambda_{N}$ ) caused by this item of internal force.

For a general beam bridge, the bending moment is the main internal force and so the section shear lag coefficient $\lambda$ is close to $\lambda_{\mathrm{M}}$. However, for concrete cable-stayed bridges, the main beam is in a compression state and is mainly subjected to axial force; its shear lag coefficient $\lambda$ is closer to $\lambda_{N}$

6.2. Theoretical versus Finite Element Main Beam Shear Lag Results. The shear lag variation law of the main beam of the single-cable PC cable-stayed bridge along the longitudinal direction was discussed above as per our theoretical analysis. The shear lag coefficient and normal stress value of the main beam cross section are mainly concentrated in the range of the force point of the cable. The effective width of the top plate of the upper flange in our analysis was set to $4.00 \mathrm{~m}$ and the full section of the bottom plate to $\sigma_{N}=0.32 \mathrm{~N}$ and $\sigma\left({ }_{-}\right)_{N}=0.09 \mathrm{~N}$ (where $N$ is the axial component of the cable force), so that $\lambda_{N}=\sigma_{N} / \sigma\left({ }_{-}\right)_{N}=3.56$. Shear lag coefficient $\lambda_{\mathrm{M}}$ was only considered a momentary action based on the definition of the effective width of the bridge. The effective width of the top plate in this case was $24.00 \mathrm{~m}$, so $\lambda_{\mathrm{M}}=1.35$.

We established the full-bridge plane bar model according to finite element analysis. The diagram of the

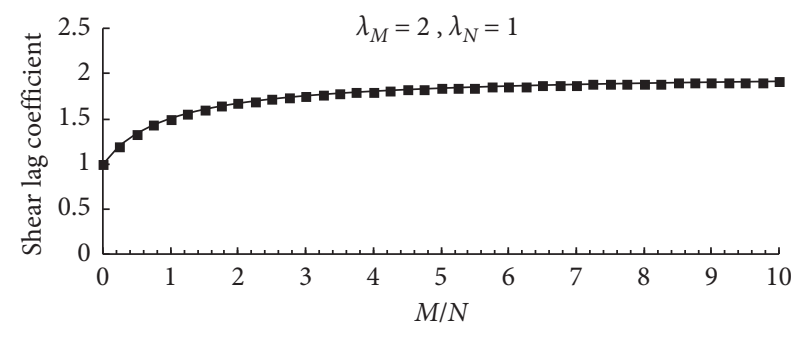

FIGURE 14: Relationship between shear lag coefficient and bending moment axial force ratio.

bending moment and axial force of the main beam under Working Condition 1 suggests relatively small internal forces in Pier $4 \#$ and the main girder of Pier 5\#. The internal force diagram of the main beam at Pier 4\# was isolated for further analysis as shown in Figure 15.

As shown in Figure 15, the bending moment force ratio $M / N$ is between $\lambda_{\mathrm{M}}$ and $\lambda_{N}$, that is, between 1.35 and 3.56. The bending moment axial force ratio $M / N$ at the action point of the cantilever end cable force $\mathrm{C} 4\left(\mathrm{C}^{\prime}\right)$ is 1.20 and 1.18. According to formula (6), the shear lag coefficient $\lambda$ of the upper edge of the main beam section is 2.35 and 2.36, respectively.

In the construction section, the axial moment ratio $\mathrm{M} / \mathrm{N}$ of the main beam section of the $\mathrm{C} 3^{\prime}-\mathrm{C}^{\prime}$ cable force action point is $1.49,1.59$, and 1.64. According to formula (6), the shear lag coefficients of the upper edge of the main beam section of $\mathrm{C}^{\prime}-\mathrm{C} 1^{\prime}$ cable force point are 2.23, 2.20, and 2.18, respectively. The axial force ratio $M / N$ of the main beam section of the C3-C1 cable force action point is $1.47,1.81$, and 2.03. Again, according to formula (6), the shear lag coefficients $\lambda$ of the upper edge of the main beam section of the C3-C1 cable force action point are 2.24, 2.13, and 2.07. Our finite element results of the shear lag effect of the main beam along the longitudinal direction suggest that the shear lag coefficient at Point $\mathrm{A}$ of the action point of cantilever end cable force $\mathrm{C} 4\left(\mathrm{C}^{\prime}\right)$ is 4.18 and 3.61; the shear lag coefficient $\lambda$ at Point $\mathrm{B}$ reaches 3.07 and 3.06 .

In the Pier $4 \#, C 3^{\prime}-C 1^{\prime}$ beam section, the shear lag coefficients $\lambda$ of Point $A$ at the cable force action point are $2.32,2.22$, and 2.49, respectively; those of Point B at the cable force action point are $1.26,1.23$, and 1.29 , respectively. Within the C3-C1 beam section, the shear lag coefficients $\lambda$ of Point $A$ at the cable force action point are 2.57, 2.71, and 2.71 and those corresponding to Point B are 2.11, 1.22, and 2.12 , respectively.

In the beam section construction stage, the analysis results of the $\mathrm{C} 3-\mathrm{C} 1\left(\mathrm{C} 3^{\prime}-\mathrm{C}^{\prime}\right)$ cable force action point treatment theory agree with the finite element analysis results. In this position, the theoretically derived shear force lag coefficient $\lambda$ can be used to reflect the actual force at that point. The finite element analysis results at the $\mathrm{C} 4$ $\left(\mathrm{C} 4^{\prime}\right)$ action point of the cantilever end cable force exceed the theoretical analysis results. The cantilever end cable force action point is mainly subjected to axial force, so its shear lag coefficient $\lambda$ should be closer to $\lambda_{N}$. In this position, the shear lag factor $\lambda_{N}$ can be used to reflect the actual force. 


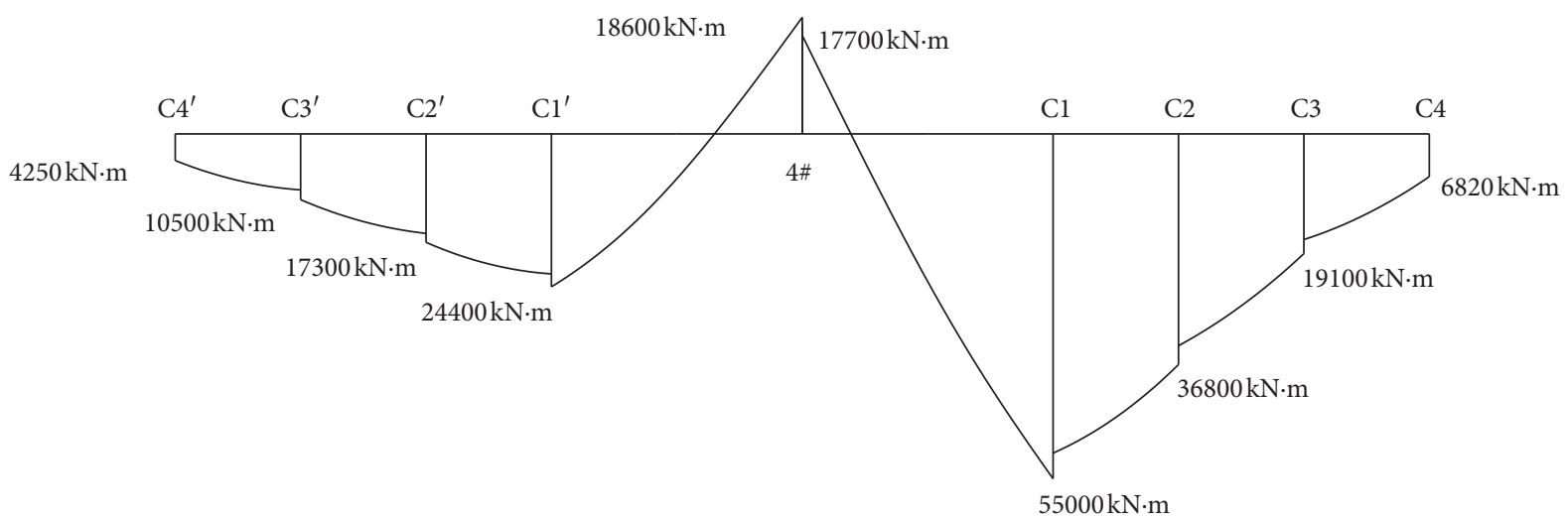

(a)

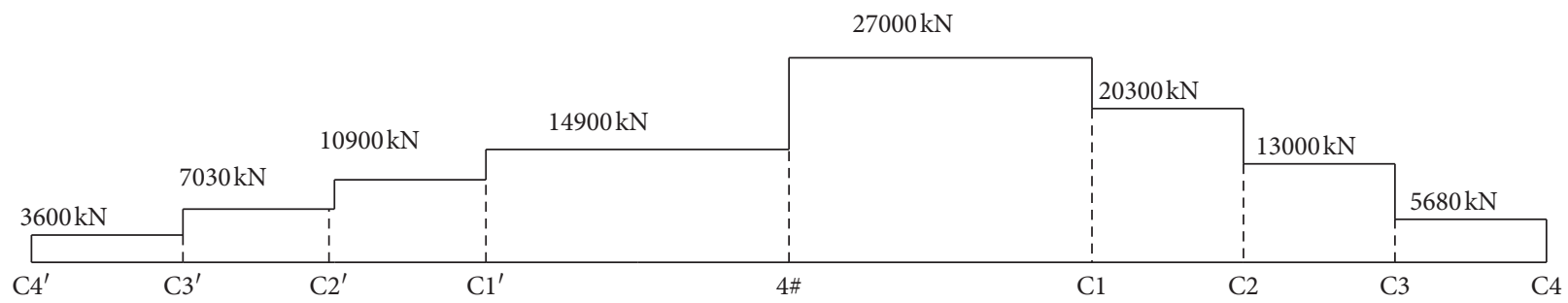

(b)

Figure 15: Internal force of main girder on Pier 4\# (Condition 1). (a) Moment diagram. (b) Axial force diagram.

6.3. Variation Law of Shear Lag Effect of PC Cable-Stayed Bridge Main Beam along Longitudinal Direction. The shear lag variations in the main beam of the single-cable PC cablestayed bridge along the longitudinal direction can be summarized as follows:

(1) In the construction stage, at the cantilever end, the cable force action point is the main recipient of axial force. The shear lag coefficient $\lambda_{N}$ of the axial force acting at this position reflects the actual force at that point.

(2) In the beam segments between the cable forces, at the cable force action point, the theoretical shear lag coefficient $\lambda$ determined by the ratio $M / N$ of the bending moment to axial force reflects the actual stress.

(3) In the midspan beam section between the action points of cable forces, the shear lag coefficient of bending moment $\lambda_{M}$ is used to reflect the actual stress. For the beam section between the action point of cable force and the middle of the span, the section shear lag coefficient is obtained by linear interpolation.

\section{Conclusion}

The structural control section stress at work in a typical construction process was measured on a full cable-stayed bridge model in this study. Sets of finite element and model test results were, respectively, analyzed and compared. Our conclusions can be summarized as follows:
(1) In the construction stage, the stress value of the cable tension area of the main beam upper edge markedly changes after tensiling the cable force; the shear lag effect is very prominent. After a hanging basket load is applied, the main beams of certain sections present alternating positive and negative shear lag.

(2) The shear lag coefficient of the upper edge of the main beam in G1-G8 sections under Working Conditions 1 and 4 was extracted from the spatial finite element analysis for comparison to find that the experimental and theoretical results are in accordance. After tension of the cable force and the application of a hanging basket load, positive and negative shear lag effects alternate on the upper edge of the box girder in certain areas. As tension cable force increases in each section, the shear lag coefficient of the section upper edge decelerates.

(3) In the construction stage, at the cantilever end cable force action point is mainly subjected to axial force. The shear lag coefficient $\lambda_{\mathrm{N}}$ of the axial force on this position reflects the actual force situation at that point. In the beam segments between the cable forces, the shear lag coefficient $\lambda$ determined by the ratio of the bending moment to the axial force reflects the actual stress at the cable force action point. In the midspan beam section between the action points of cable forces, the shear lag coefficient $\lambda_{M}$ of the bending moment reflects the actual stress. For the beam section between the cable force action point and the middle of the span, the section shear lag coefficient can be obtained by linear interpolation. 
(4) The shear lag effect of the main beam is prominent in the construction process. The shear lag effect is most obvious at the cable force operation point of the cantilever end. As construction progresses and the cable force increases, the shear lag effect of other beam sections decreases at each point except for the cantilever end.

\section{Data Availability}

Part of the shear lag coefficient data used to support the findings of this study are included within the article. All of the shear lag coefficient data used to support the findings of this study are available from the corresponding author upon request.

\section{Conflicts of Interest}

The authors declare that they have no conflicts of interest.

\section{Acknowledgments}

The authors would like to thank the financial supports from the National Key R\&D Program of China (2018YFC0809600 and 2018YFC0809606) and Natural Science Foundation of Liaoning Province (2019-MS-265).

\section{References}

[1] Z. Li, J. G. Nie, and W. Y. Ji, "Positive and negative shear lag behaviors of composite twin-girder decks with varying crosssection," Science China Technological Sciences, vol. 60, no. 1, pp. 116-132, 2017.

[2] S.-J. Zhou, "Finite beam element considering shear-lag effect in box girder," Journal of Engineering Mechanics, vol. 136, no. 9, pp. 1115-1122, 2010.

[3] Z. Li and R. K. L. Su, "Analytical solutions for composite beams with slip, shear-lag and time-dependent effects," Engineering Structures, vol. 152, pp. 559-578, 2017.

[4] Q. Z. Luo, Y. M. Wu, Q. S. Li, J. Tang, and G. D. Liu, "A finite segment model for shear lag analysis," Engineering Structures, vol. 26, no. 14, pp. 2113-2124, 2004.

[5] P. Z. Lin, F. K. Liu, W. Ji et al., "Analysis on shear lag effect of concrete box beam by variational principle," Journal of the China Railway Society, vol. 35, no. 2, pp. 93-98, 2013.

[6] Y. Y. Zhang, H. Zhang, W. Li et al., "Analysis on shear-lag effect of box girders based on different shear-lag generalized displacement," Journal of Railway Science and Engineering, vol. 13, no. 6, pp. 1083-1090, 2016.

[7] S. T. Chang, Q. Zhang, and S. Zhang, "Shear lag effect in single plane cable-stayed bridge," Advances in Structural Engineering, vol. 1, no. 4, pp. 301-306, 1998.

[8] G.-F. Wu and X. Hong, "Theoretical and experimental study on shear lag effect of partially cable-stayed bridge," Journal of Zhejiang University-Science A, vol. 6, no. 8, pp. 875-877, 2005.

[9] L. Pengzhen, Y. Zijiang, L. Fengkui et al., "Shear lag effect of concrete box girders considered varying flange-depths," Journal of Civil, Architecturale Environmental Engineering, vol. 35, no. 1, pp. 76-79, 2013.

[10] E. Yamaguchi, T. Chaisomphob, J. Sa-Nguanmanasak, and C. Lertsima, "Stress concentration and deflection of simply supported box girder including shear lag effect," Structural Engineering and Mechanics, vol. 28, no. 2, pp. 207-220, 2008.
[11] X. B. Shen, "Analysis of shear lag effect in the main girder of wide low-pylon cable stayed bridge," Construction Technology, vol. 44, no. 24, pp. 76-79, 2015.

[12] L. Xingmin, "Analysis of influences of construction processes on shear lag effect of concrete box girders," Bridge Construction, vol. 43, no. 1, pp. 30-34, 2013.

[13] L. Muyu, W. H. Sun, X. D. Sun et al., "Stress analysis of wider girder of an extradosed cable-stayed bridge based on the largest cantilever construction stage," Journal of Huazhong University of Science and Technology (Urban Science Edition), vol. 27, no. 2, pp. 11-14, 2010.

[14] C. Qianshu, H. Wenlong, and Y. Menggang, "Analysis of shear lag effect in construction stage of wide box girder extradosed cable-stayed bridge with large flanges," Journal of Railway Science and Engineering, vol. 15, no. 12, pp. 31583164, 2018.

[15] D. R. Li, B. M. Wang, and Y. C. Lin, Structural Model Experiment, Science Press, Beijing, China, 1996.

[16] J. W. Dali and W. F. Laili, Experiment and Analysis of Residual Stress, Ocean Press, Beijing, China, 1987.

[17] H. Hossdort, Structural Model Analysis, China Architecture \& Building Press, Beijing, China, 1986.

[18] S. K. Mei, Structural Experiments and Structural Design, China Communications Press, Beijing, China, 1980.

[19] B. Atmaca and S. Ates, "Construction stage analysis of threedimensional cable-stayed bridges," Steel \& Composite Structures, vol. 12, no. 5, pp. 413-426, 2012.

[20] S. W. Park, M. R. Jung, D. J. Min, and M. Y. Kim, "Construction stage analysis of cable-stayed bridges using the unstrained element length method," Journal of The Korean Society of Civil Engineers, vol. 36, no. 6, pp. 991-998, 2016.

[21] M. Gunaydin, S. Adanur, A. C. Altunisik, B. Sevim, and E. Turker, "Determination of structural behavior of Bosporus suspension bridge considering construction stages and different soil conditions," Steel and Composite Structures, vol. 17, no. 4, pp. 405-429, 2014.

[22] S. Adanur, M. Günaydin, A. C. Altunişik, and B. Sevim, "Construction stage analysis of humber suspension bridge," Applied Mathematical Modelling, vol. 36, no. 11, pp. 54925505, 2012.

[23] J. B. Mander, M. J. N. Priestley, and R. Park, "Theoretical stress-strain model for confined concrete," Journal of Structural Engineering, vol. 114, no. 8, pp. 1804-1826, 1988.

[24] Y. A. Khalid, C. L. Chan, B. B. Sahari, and A. M. S. Hamouda, "Bending behaviour of corrugated web beams," Journal of Materials Processing Technology, vol. 150, no. 3, pp. 242-254, 2004.

[25] A. Demir, N. Caglar, H. Ozturk, and Y. Sumer, "Nonlinear finite element study on the improvement of shear capacity in reinforced concrete $\mathrm{T}$-Section beams by an alternative diagonal shear reinforcement," Engineering Structures, vol. 120, pp. 158-165, 2016. 